\title{
Lærer Alfred Torps optegnelser fra et ophold i Tønder
}

Udgivet ved Peter Kr. Iversen.

III.

Til orientering for de mange nye medlemmer og lasere meddeles, at de to forste dele af Alfred Torps optegnelser findes $i$ Sonderjyske Arbøger 1963, s. 1-57 og 89-152.

\section{9}

8. januar. Frk. Agnes Smidt fra Lundsmark ved Hviding var i dag her $\mathrm{i}$ byen for at tale med forskellige, der kunne give hende oplysning om det, der kendetegner hjemmetyskernes væsen og ejendommeligheder; hun vil gerne have Svendsen til at skrive et skuespil med dette grundmotiv. Jeg talte med frk. Smidt hos sygehusinspektør Jacobsens; hun syntes, at både tyskerne og danskerne skulle og kunne lære af hinanden; jeg fremhævede, at dette i hvert fald for tyskernes vedkommende også er tilfældet; hjemmetyskeren bliver ubevidst $\mathrm{i}$ den grad inficeret af dansk væsen og tankegang, at de daglig kommer os nærmere og vistnok føler sig vel derved.

10. marts. I forgårs afholdtes byrådsvalg med det resultat, at tyskerne gik tilbage fra 49 til $45 \%$ af samtlige stemmer; ikke desto mindre vandt de et mandat - ved et mærkeligt tilfælde: Socialdemokraterne havde en sådan stemmefremgang, at danskerne måtte miste et mandat til dem. Da der imidlertid var to socialdemokratiske lister uden listeforbund (to stridende parter: sagfører Bundgaard og redaktør Petersen), kunne socialdemokraterne ikke fastholde den gevinst, der således gik over til tyskerne. Herefter har vi i de kommende fire år rent tysk flertal (f. t. mod 5 danske og 2 socialdemokrater). Tiden skal vise, hvad dette 
flertal skal bruges til; jeg tror egentlig ikke, det vil blive misbrugt; dog må man regne med, at de, der eventuelt bliver ansat i byens tjeneste $i$ den kommende tid, alene bliver taget af tyskernes rækker.

12. marts. Den nyvalgte socialdemokrat hævder, at han ikke kan forstå en tysk forhandling, han skal derfor have udtalt, at han vil forlange, at borgmesteren også forelægger sagerne på dansk, hvis han som nu fortsætter med tysk. Dette er jo et meget moderat standpunkt; nu gælder det blot om at finde den rette form, hvorunder kravet kan gennemføres; en stor sprogdebat for åbent tæppe $i$ et byrådsmøde er vi danske ikke interesseret $\mathbf{i}$; da får vi antagelig lidenskabelige scener, der skærper modsætningen mellem de to befolkningsdele, som vi onsker stadig formindsket ved roligt samliv. For den tyske presse er den slags "gefundenes Fressen ", som der kan leves højt på længe. I den danske byrådsgruppe bør vi søge sagen løst uden offentlig forhandling.

18. marts. I den nyvalgte danske byrådsgruppes forste møde i dag fik ovenstående standpunkt i sprogspørgsmålet enstemmig tilslutning, og bankdirektør Andresen og jeg valgtes til at forhandle med redaktor Petersen for at blive klar over hans krav i sprogspørgsmålet og for dermed at få klarhed over, om den danske gruppe bør optage en underhåndsdebat med borgmesteren for at få spørgsmålet løst uden om offentligheden.

Under disse forhandlinger kom borgmester Thomsen ind til os - drivende fuld! Han har vist ikke været meget ædru siden byrådsvalget, hvor han iøvrigt opnåede det enestående høje tal af 800 personlige stemmer (Th. Petersen f. eks. havde 135, hvilket også er et højt tal). På hele valgdagen var han beruset; under stemmeoptællingen, medens de mange personlige stemmer som et tillidsvotum fra hans bysborn regnede ned over hans hoved, kom han ned $\mathrm{i}$ afstemningslokalet så påvirket af spiritus og så støjende, at en mindre højtstående i den lille by var blevet bragt til politistationen. Den tyske lærer Gläser udbrød forarget: "Han skulle overhovedet ikke have lov at komme her: Men det er iøvrigt karakteristisk for tankegangen i Tønder, at der sikkert var mange af de tilstedeværende både tyske og danske, der halvvejs beundrede borgmesteren. Han er $\mathrm{i}$ det hele taget afholdt på grund af sin godmodighed, og det store personlige stemmetal må 
tages som en tilkendegivelse af, at den tyske befolkning ønsker ham og ikke den tyske redaktør Fr. Andresen (eller den danske Thorvald Petersen) til borgmester.

20. marts. Bankdirektør Andresen og jeg fik ved vor samtale med redaktør Petersen $i$ dag det indtryk, at han ville stille så naturlige og moderate krav og på en sådan måde, at der ikke var nogen grund til for vor gruppe at forhandle med borgmesteren, der iøvrigt $i$ en privat samtale med Andresen havde erklæret, at han gerne skulle forelægge sagen på dansk, når Petersen virkelig ikke forstod tysk.

Redaktør Petersen kan vist ikke meget tysk og siger, at han med vilje ikke har lært sig sproget, fordi han ikke vil give næring for den opfattelse, at man må kunne tysk for at udøve en redaktørvirksomhed i Tønder. Det kan jo være meget rigtigt, men for at fả det fulde udbytte af livet her, hvor to kulturer modes og begge byder os noget betydeligt, må man nu kende begge sprog; dette må særlig gælde for redaktøren inden for det socialdemokratiske parti, som jo netop rummer begge nationaliteter og vil forene dem.

11. april. Tyskernes skolepolitiker, rektor Koopmann, henvendte sig $\mathrm{i}$ dag til Svendsen og bad om hans råd $\mathrm{i}$ anledning af, at han havde taget den beslutning, at hans søn skulle tage sin studentereksamen pâ en dansk skole, efter at han nu havde taget tysk realeksamen; da Koopmann ønskede, at sønnen skulle på en skole nord på, ville han bl. a. gerne have en skole anbefalet. Koopmann udviklede det interessante standpunkt, at han ikke ønskede sønnen syd på, fordi han var bange for, at de unge, der uddannede sig der, blev fremmede for deres hjemstavn og så efter endt uddannelse måske ikke ville eller kunne (med held) tage en virksomhed op her. Blev de derimod uddannet i Danmark, ville de ikke blive fremmede for deres landsmænd. Desuden er henvendelsen et godt udtryk for den store tillid, som tyskerne viser Svendsen. Men tilfældet leder jo tanken hen på det uløste spørgsmål om højere tyske skoler; vi har hidtil sagt, at det var bedst, om de unge tyskere blev uddannet her i landet, og nu er tyskerne ogsâ af den opfattelse, at det er klogest for dem.

12. april. Da vi ved byrådsmødet $i$ aftes havde behandlet de tre-fire første mindre betydelige punkter på dagsordenen, blev 
der givet udtryk for det tidligere omtalte sprogspørgsmål, idet redaktør Petersen rejste sig og bemærkede:

»Der er ved behandling af denne sag (levering af sten til Strucks Allé) faldet nogle tyske udtalelser, som jeg må anmode om at få oversat, da jeg ikke forstår tilstrækkeligt tysk; da de tre først behandlede sager ikke var så vigtige, stiller jeg først dette krav nu«. Borgmesteren: »Jeg kan virkelig ikke huske, hvad jeg har sagt, så det vil ikke være let at opfylde hr. Petersens onske". Redaktør Petersen: Borgmesteren må dog kunne give et kort resumé på dansk «. Borgmesteren: "Jeg præparerer mig virkelig ikke således til møderne, at jeg skulle kunne gengive min tale $\mathbf{i}$ enkeltheder; men jeg skal forsøge at meddele det vigtigste «. Derefter forsøgte han derpå, men hans "resumé « havde dog ikke meget lighed med hans første udtalelser. Han var heller ikke ædru. Forhandlingen forløb under rolige former, omend den tydeligt nok spændte forventningerne om, hvad der kunne ske. Det er, som om begge parter på een gang føler det som noget pinligt og samtidigt er på vagt, når den slags forhandlinger opstår - hvilket sker yderst sjældent. Hvad selve sagen angår, kan det bemærkes, at borgmesteren fortsat kun forelagde sagerne på tysk. Længere hen på aftenen sagde Petersen derfor ved en anden sags behandling: "Hør, borgmester kunne De ikke lige sige mig indholdet af denne sag på dansk *. Dette skete så, men nogen principiel løsning $i$ retning af, at borgmesteren skulle forelægge sagerne i begge sprog, fik vi således ikke, og det kommer formentlig deraf, at redaktør Petersen ikke ved mødets begyndelse rejste sine krav i sprogspørgsmålet principielt, men stillede sine ønsker fra sag til sag. Nu er borgmesteren jo ligefrem indstillet $i$ den retning, og hvis der ikke sker noget særligt, må man vente, at han i fremtiden kun taler dansk i hvert enkelt tilfælde, hvor det forlanges.

27. april. Amtsskolekonsulenten fortalte $i$ dag, at han havde aflagt besøg ved skolen i Højer. Forholdene har udviklet sig på den skønneste måde; børnene fra de to afdelinger blandes i korridoren mellem hverandre og leger derefter sammen på legepladsen. Ligeledes enes de to afdelingers lærere på bedste måde, og ved den forestående hovedrengøring skulle den ofte omtalte kejserbuste ud (som et symbol vel på de nye fredelige forhold), 


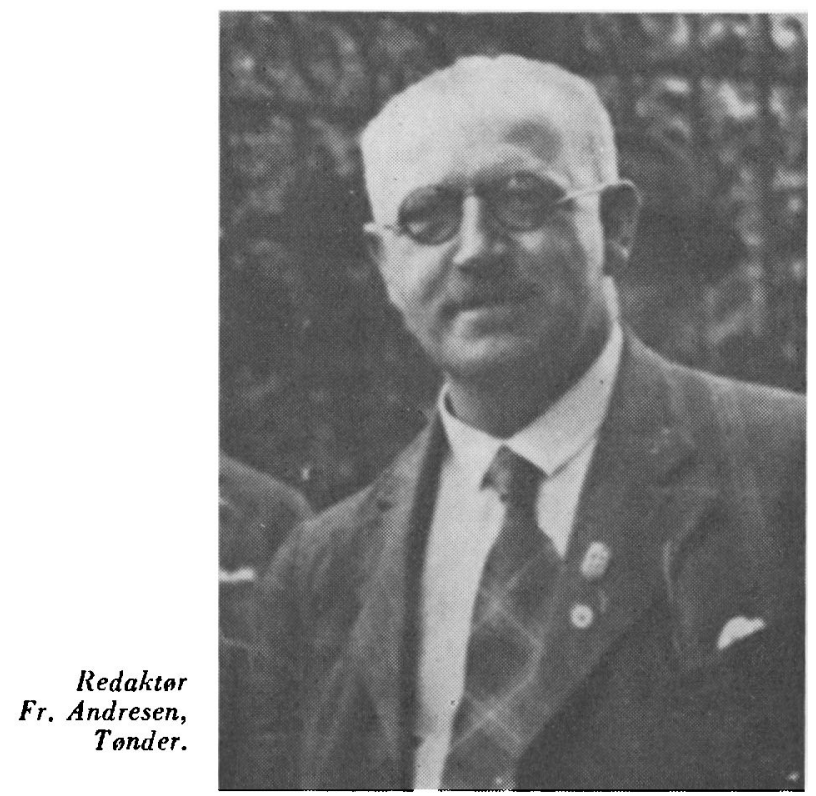

skønt Svendsen aldrig har haft noget imod, at busten blev stående som et kuriosum. Udviklingen i Højer er et udtryk for, hvad der sker, når der er fred og ro; så vokser alt sig til rette af sig selv - i vor favør.

28. april. Ved folketingsvalget den 24 . ds. gik tyskerne over $1 \%$ tilbage af samtlige afgivne stemmer. Dette har naturligvis vakt glæde og fortrøstning $\mathrm{i}$ danske kredse; det viser, at tyskernes vinding $i 1926$ var en konjunktursejr, og at der er bestemte grænser for, hvad tyskerne kan nå, selv med nok sâ gode organisationer. Hvis nu de økonomiske forhold udvikler sig på en god måde, tør man regne med en fortsat tysk tilbagegang. Jeg tror, at tyskerne har mange af den slags folk, hvis energi kun er levende under medgang, og som slappes og måske helt mister interessen i modgang; fortsat tilbagegang $i$ det tyske stemmetal vil have sin store psykologiske betydning. Mine kolleger på skolen har været meget stilfærdige efter valget, og »Nordsleswigsche Zeitung « har jo bragt meget få valgkommentarer til belysning af tyskernes stilling. Den nye regering, vi nu kan vente, kan gøre meget for at fremme den gode udvikling hernede. - Assimila- 
tionen med Danmark - blandt andet ved at fore det store udstykningsforslag igennem, men også ved store kultiveringsarbejders udforelse, hvorved der bliver plads for mennesker og arbejde for ledige hænder - alt medvirkende til at skabe den tilfredshed, som får befolkningen til at leve sig ind til Danmark.

1. maj. Tirsdag den 30. april deltog jeg i et fortroligt møde på Gråsten landbrugsskole, hvor dr. Lausten-Thomsen som indledning til en forhandling talte om "Dansk arbejde i Sønderjylland efter genforeningen". Hans foredrag var, som en af deltagerne i diskussionen senere sagde, sen lovprisning af Danmark og hvad dansk er«. Han gav blandt andet smukt udtryk for troen på, at Danmarks store arbejde siden genforeningen på rent praktisk område har sine overordentlige store sidevirkninger i national henseende og drager mange tysksindede ad vore veje. I forhandlingen deltog mange af Sønderjyllands bedste mænd; jeg vil gengive enkelte vigtige ting, som fremkom under forhandlingen:

Gårdejer Schmidt, Vojensgård: Tyskernes organisations- og privatskolebevægelse er udtryk for alt for store rammer; der er ikke tilstrækkeligt indhold; de ønsker at opnå dette ved at vinde de sblakkede», hvis jord de også gerne vil sikre sig. Valget ville have sin store betydning blandt andet ved at virke opmuntrende i danske kredse; kampen om jorden bliver fortsat, her må vi passe på.

Biskop, dr. Amnundsen, Haderslev: Man mærker, at bedst som man tror, at talen om forskellen mellem sønderjyder og tilflyttede danske og især mellem disse og de tysksindede er ved at forstumıne, viser den sig igen. Biskoppen gav $i$ den henseende en dame ret, der $i$ et selskab hos ham havde udtalt: "Men hvad gør det også, at vi ikke får denne sammensmeltning fuldt ud at se; enhver af os kan jo se, hvorledes børnene lever sig sammen, og hvad gør det så, at vi bliver overgangstyper‘. Vi skal være glade for at få lov til at leve med hernede netop i denne tid og betragte det som en ære at tjene her. Jeg kunne ikke et øjeblik tænke mig at vende tilbage og har ikke på noget tidspunkt onsket, om end jeg må sige, at bevægelserne var ved at falde mig på nerverne. Mange udtalelser fra den tid gjorde mig ondt og overraskede mig; men man må jo forstå, at sønderjyderne $i$ et kort åremål har gennemgået så meget, at mange tabte målestokken for, hvad der 
er muligt, og således kunne tro på Cornelius Petersens forvildede planer.

Pastor Eriksen, Asserballe: Vi skal tænke på i al vor færd at være venlige og naturlige jævne, hvis vi vil vinde befolkningen; i Lysabild virker en tysksindet doktor. Da han har dansk uddannelse, virker han ikke i nogen måde fremmed, og da han tillige er venlig og virkelig tiltalende, er han en meget farlig mand for os. Tyskerne vil sikkert stræbe efter at få akademikere af den type anbragt i Nordslesvig; vi må have vor opmærksomhed henledț på den sag og tænke på at få dygtige, danske akademikere til at optage en gerning $i$ landsdelen.

H. P. Hanssen: Der har i dag været tale om det uheldige i, at så mange tyske præster og lærere forblev i Sønderjylland. For præsternes vedkommende skyldes det den lange overgangstid, der gik hen, inden genforeningen blev fuldbyrdet; de benyttede da lejligheden til at skabe en gunstigere stemning for sig blandt befolkningen, der så i overordentlig mange tilfælde genvalgte dem ved de følgende præstevalg. Dette er et udtryk for det, som vi oplever også i andre henseender, at man kan være så retfærdig, at man bliver ubillig mod sig selv. - - Blandt hjemmetyskerne står man også over for en udvikling af senere dato; som eksempel herpå kan nævnes Lei, $i$ hvis hjem jeg har været til stede ved en fest, hvor gamle Reimers fra Sønderborg begejstret talte om Danmark og udbragte et dansk leve, der kraftigt besvaredes af de tilstedeværende. Men mange hjemmetyskere vil nok samarbejde med os danske på faglige områder; en del unge tyske er gået ind i de danske landboforeninger, og jeg finder det glædeligt, at man her og der har indvalgt sådanne i bestyrelsen. - - Der er en bevægelse, vi skal passe på, nemlig det stadig forøgede krav om at få timer i tysk i de danske skoler; bevægelsen i denne retning er i en meningsløs grad livlig på Als, og ved den forestående, almindelige revision af undervisningsplanerne må vi passe på overfor krav om ændringer i retning af at indføre tysk eventuelt på andre fags bekostning. Det farlige ligger også deri, at man da i fremtiden må søge lærere til de pågældende skoler, der kan tysk, således at alle de lærere, der ikke kan det, på forhånd bliver skudt ud. Vi skal ikke lade os vildlede af den tyske privatskolebevægelse, selv når den udfolder sig i de nordligste egne; det er 
ofte børn, der samles fra en stor omkreds, der går i skolen. Eleverne i Sommersted tyske privatskole har således fået udleveret gratis cykler, fordi de har så lang vej til skole; penge mangler tyskerne jo ikke, heller ikke til sådanne formål. Vi skal være varsomme med indrømmelser til et højere tysk skolevæesen; hvis et tysk privatskolegymnasium får eksamensret, kan de mange "blakkede" tænke, at det er fordelagtigt at sende deres børn på en sådan skole, idet de så senere kan studere både i Kobenhavn og ved et tysk universitet. Desværre må man regne med, at den nye regering $i$ henhold til Herning-overenskomsten vil opfylde de tyske skolekrav. - - I det lange lob er det vor styrke, at det ydre mere og mere præges af, hvad der er dansk. Jeg har ladet foretage en undersøgelse af, hvad hjemmetyskerne læser af blade og tidsskrifter, og det viser sig, at langt den største del læser danske aviser. Til Tinglev postkontor var i 1920 anmeldt 72 tyske aviser; nu er der kun anmeldt en. Og ganske afgjort har de danske illustrerede blade sejret over de tyske, som man jo ikke ser meget til.

Til dette oplyste en yngre præst, at tyskerne stærkt har deres opmærksomhed rettet mod dette forhold, og der er indledt en modaktion. I grænseområdet cirkulerer mapper med tyske blade; på en mappe kan der abonneres mod en ringe betaling. På det område frygter jeg nu ikke konkurrencen, fordi de tyske blade ikke er, som befolkningen ønsker dem - deres indhold er fremmed for befolkningen, hvis bevidsthedsindhold bliver rent dansk efterhånden, og naturligvis virker det tyske sprog også hæmmende; de børn på landet, som ikke netop går i en tysk skoleafdeling, kender som regel lige så lidt til tysk, som børn i det gamle land.

I slutningen af forhandlingen udtalte landbrugskonsulent Hans Hansen, Gråsten, at han på sine mange besøg også hos hjemmetyskerne havde fået det indtryk, at der hersker megen utilfredshed med Vogelgesang på grund af den skrappe måde, han behandler sine låntagere på. - - Om mødet som helhed kan siges, at det vel har sin værdi, omend der blev sagt særdeles meget, som er sagt flere gange før ved lignende fortrolige møder; jeg tror, det nu var mere på sin plads at drøfte løsningen af praktiske opgaver. Kreditforeningsdirektor Callø talte under megen tilslutning 
om, at hele det praktiske liv virker så uhyre $i$ vor faver, også $i$ national henseende; der virkes $i$ virkeligheden for os hele tiden, men der virkes bedst $i$ ro; derfor er det godt, at den offentlige drøftelse om tyskerne og nationale opgaver ikke bliver alt for omfattende. Vi kan arbejde i rolig tillid til, at vi må og skal vinde det er et tidsspørgsmål.

13. maj. Ved byrâdsmødet den 10. ds. forlangte redaktør Petersen kun ved et par småsagers behandling dansk oversættelse; der er således fra hans side ikke i mindste måde givet bidrag til en principiel løsning af sprogspørgsmålet. Borgmesteren fortsatte med og vil formentlig også i fremtiden udelukkende forelægge sagerne på tysk.

28. maj. Under et pinseophold i København i anledning af Det radikale Venstres landsmøde indbød $H$. V. Clausen mig på tur til Frederiksborg Slot for at se Visby-fundene. Det meste af en dag gik dermed - det blev en af de ture, jeg husker; man får ikke let bedre selskab end Clausen. Samtalen blev naturligvis en gennemgang af sønderjyske forhold i fortid og nutid. Clausen meddelte, at det historiske atlas, hvortil jeg sammen med overlærer Skovmand (Løgumkloster) har givet et udkast, nu vil blive udarbejdet blandt andet med Skovmands og min medvirken. Atlasset vil blive for Sønderjylland alene, og 1600 eksemplarer vil blive uddelt gratis til grænseområdets danske skoler. - - Under en omtale af sit ophold ved fredskonferencen i Paris fortalte Clausen, at prins Axel skulle deltage i en frokost hos Poincaré; Clemenceau ville være til stede, og samtalen ville selvfølgelig komme til at dreje sig om Danmarks nye grænse. Prinsen skulle derfor instrueres; i økonomisk henseende var det let (Ø.К.); derimod var det ikke så lige til at overbevise ham om det rigtige $i$ regeringens stilling til grænsespørgsmålet. En konge udvider sit lands grænser, så langt det er muligt «, sagde prinsen. - - Sammen med Clausen og mig gik et større tysk rejseselskab - tilsyneladende gymnasielærere gennem slottet; føreren gav grundig besked, skønt han gjorde indtryk af også at være fremmed. I genforeningsværelset med Hans Nic. Hansens kongebilleder udtalte han: D Dette værelse kan ikke glæde os tyske, fordi det er en erindring om det land, vi har mistet i Slesvig. Men vi må jo ikke glemme, at der i området var $75 \%$ danske stemmer, og at vore 
landsmænd der bliver behandlet på den allerbedste måde. Mens de hele tiden har fået $50 \mathrm{kr}$. i tilskud pr. barn i private skoler, fik i lang tid danskerne syd for grænsen intet tilskud, senere bød man dem fem mark, og først nu er der indtrảdt ligestilling. På billederne her ser De den ovenud populære konge tagende det generhvervede land $\mathrm{i}$ besiddelse. Slesvigerne havde troet at komme til et land, der flød med mælk og honning, men i så henseende er de blevet skuffet; de har haft megen økonomisk modgang «.

I indenrigsministeriet havde jeg en lang samtale med den nye minister Bertel Dahlgaard, som jeg - i fortsættelse af samtaler før hans ministerudnævnelse - ville interessere for nogle grænsepolitiske opgaver. Jeg fremhævede, at netop denne regering, hvis partier havde æren og ansvaret for den grænse, vi fik, måtte have en ganske særlig interesse i også at styrke grænsen ved kulturelt og økonomisk arbejde. Dette synspunkt anerkendte ministeren fuldt ud og bad mig pápege forskellige opgaver. Jeg udviklede da, hvorledes stillingen lå med hensyn til Det Kongelige Teater og spurgte, om en henvendelse fra Sønderjylland til undervisningsministeren nu ville være det rette. Ministeren udtalte hertil, at sagen havde hans store interesse, og at han derfor ønskede, at den skulle tages op af regeringen. Han ville bringe den på bane i første ministermøde og håbede så, at det i særdeleshed skulle lykkes at interessere undervisningsminister Borgbjerg for den. Dermed havde jeg opnået så meget, som jeg kunne, i den sag; jeg håber nu, at »de skjulte kræfter", der virker i teatersager ikke overstiger regeringens. - - Jeg påpegede forskellige kultiveringsarbejder i Sønderjylland, som blandt andet burde udføres ud fra den tankegang, at vi må have liv og bevægelse i grænseområdet, således at sønderjyderne kan leve og arbejde sig sammen med Danmark. Dahlgaard spurgte om, hvad indtryk det ville gøre, at Niels Frederiksen skulle lede det forestående udstykningsarbejde (de 10 mill. kr.). Jeg svarede, at det havde virket godt, fordi befolkningen i sådanne sager — og i særlig grad denne - tænker rent sagligt og ikke partipolitisk. Iøvrigt påpegede jeg, at store kredse knytter deres forhåbninger om den nationale fremtid til de store udstykningsarbejder, som vil give landsdelen en befolkningsmængde som de øvrige landsdele, hvorved det tyske min- 
dretals tilstedeværelse selvfølgelig kommer til at rumme en langt mindre fare for Danmark. Den grænsepolitiske spænding kan da ventes afslappet - og vi vil føle os stærke nok til i fuldkommen grad at lade mindretallet leve og udfolde sig, og da vil der være de rette betingelser til stede for, at vi også i langt højere målestok vil kunne se, hvilken rigdom tilstedeværelsen af et nationalt mindretal kan betyde for os, og drage udbytte deraf. - Dette synspunkt bifaldt ministeren $i$ enhver henseende og udtalte, at som rigsdagsmand havde ingen sag (for ham) haft så stor interesse som grænsespørgsmålet; han bad mig om til enhver tid at henvende mig til ham mundtligt eller skriftligt i sønderjyske anliggender. Under vor samtale havde jeg omtalt, at Dybbøldagens midler $i$ alt for høj grad går til opgaver syd for grænsen til skade for danske interesser nord for grænsen. Dahlgaard satte mig derefter i forbindelse med justitsminister Zahle, over for hvem jeg udviklede, at der som betingelse for tilladelse til at afholde Dybbøl-dagen burde forlanges, at en vis del, f. eks. halvdelen, af det indkomne beløb burde anvendes nord for grænsen. Zahle var ganske enig i dette standpunkt og spurgte, om jeg onskede, at han skulle skrive derom til Grænseforeningen. Det ønskede jeg ikke, men bad ham tage en mundtlig forhandling om sagen, når Grænseforeningen igen kommer for at fả lov til at afholde dagen. Den fremgangsmåde fandt Zahle også heldigst, han nedskrev indholdet af mit standpunkt på et papir, der ville blive lagt til sagens akter. - Ministeren udtalte ved afskeden på venligste måde, at han altid gerne ville høre fra mig i sønderjyske anliggender, og at han havde fuld tillid til mig.

30. maj. I går besøgte kongen og dronningen Tønder. Besøget og modtagelsen på Torvet forløb i det dejlige sommervejr på bedste måde. Også de fleste tyske byrådsmedlemmer var kommen til stede og tog meget pænt på sagen. Der var naturligvis opstillet en stor mængde skolebørn, hvoraf de fleste måske var fra de tyske skoler; man ser ved en sådan lejlighed, at det politiske spiller en stadig mindre rolle; de tyske børn fulgte modtagelsen med ikke mindre interesse end de danske og glædede sig som disse, da kongen gik hen imellem dem og talte med enkelte. - Den tyske avis skriver $i$ dag velvilligt om besøget og kongens tiltalende måde at optræde på. 
31. maj. Ved byrådsmødet i går aftes glemte borgmesteren ikke at overbringe en hilsen til byen, som kongen ved taflet på "Dannebrog " havde bedt ham overbringe byen. Han bemærkede, at han havde haft en plads meget nær ved Hans Majestæt, der havde udtalt de bedste ønsker for byens økonomiske fremtid.

6. juni. Amtsskolekonsulent Svendsen og jeg besøgte i dag H. P. Hanssen i Åbenrå, som lige er vendt hjem fra mindretalskonferencen i Madrid. Da vi trådte ind i stuen, sad han ved kaffebordet og var midt $i$ en livlig omtale af de store tyrefægtninger, han havde overværet i Barcelona. - Hanssen taler med ikke mindre livfuldhed om en tyrefægtning end om den interessanteste politiske sag. - Han fortalte, at endog blandt ledende konservative politikere i Tyskland var der ved at fremvokse en forståelse for, at den dansk-tyske grænse kunne der ikke røres ved. Stresemann holder - fortalte Hanssen - hver fredag teaften for udenlandske pressefolk og fremmede magters presseattacheer til information for disse, som kan stille spørgsmål om politiske anliggender. En af dem havde en aften spurgt, om det ikke var bedre, at mindretallene assimilerede sig. Stresemann udtalte, at det kunne der ikke være tale om f. eks. i Polen, hvor det tyske mindretal er stort, og hvor der er stærke nationale modsætninger til stede; men derimod kunne han udmærket tænke sig, at en sådan assimilation fandt sted med tyskerne i Danmark. - Hvis ikke denne udtalelse var fremsat for at berolige den danske presseattache, er den jo meget glædelig.

14. juni. En lille skolepige (... af den kendte bondefamilie) fortalte mig i dag, at hun nu næsten kun talte dansk hjemme, fordi de havde fået tjenestepige fra Fyn, der jo ikke kunne tysk. Pigen var dygtig og rar, og hun holdt meget af hende. Samtidig fortalte hendes jævnaldrende kusine ..., at nogle af karlene hjemme også var "fra Danmark", og at hun derfor også nu talte meget dansk hjemme. - Således fremmes den sproglige udvikling på naturlig måde $i$ det praktiske liv.

16. juni. Genforeningsfesten i går aftes blev særlig vellykket, fordi der var over hundrede gæster fra Odense til stede. Sådanne sammenkomster (et lignende skete i Åbenrå, hvor et stort antal sjællændere var mødt) har naturligvis en god indflydelse $i$ det praktiske genforeningsarbejde. Der er ingen tvivl om, at gæsterne 


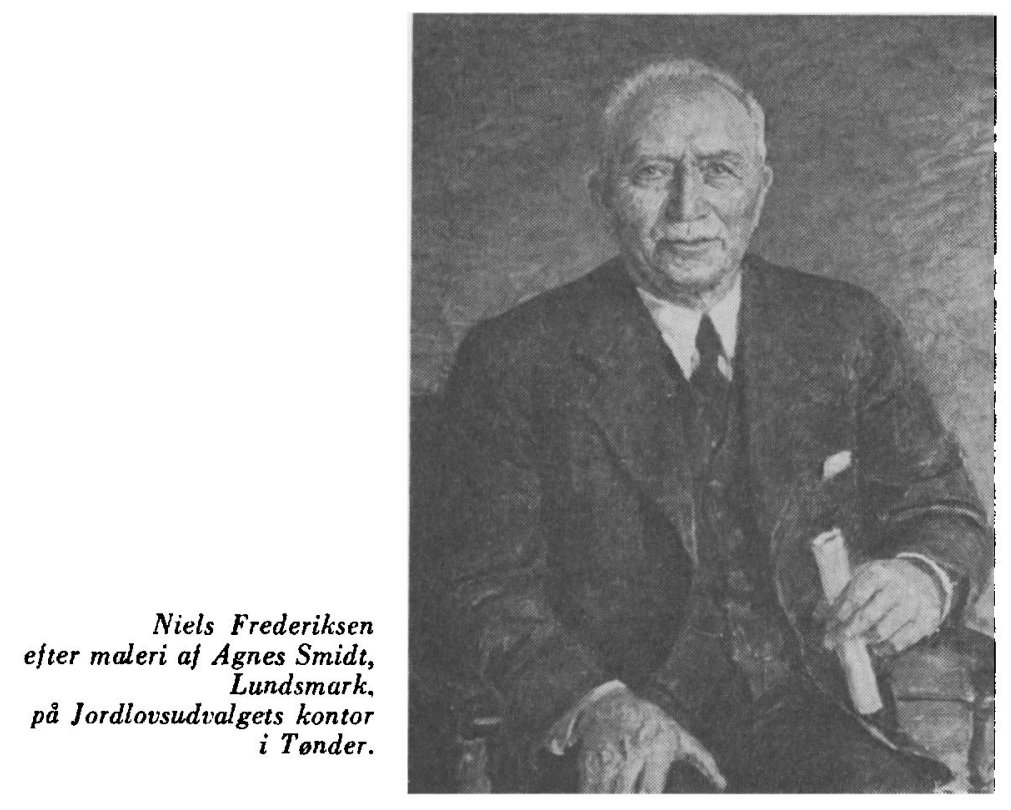

- der også er her i dag - tager et både forøget kendskab til og interesse for grænseforholdene med sig hjem; en sådan udvikling blandt befolkningen nord på er naturligvis meget ønskelig, og i kommende år vil der antagelig systematisk blive indbudt gæster nord fra til vore genforeningsfester.

19. juni. Folketingsmand Niels Frederiksen, som skal lede det store udstykningsarbejde i grænseområdet, hvortil der er bevilget 10 mill. kr., kom i går hertil sammen med sin kone og tog ophold på "Tønderhus «. Han gav udtryk for mange betænkeligheder ved gennemførelsen; han var bange for, at jorden skulle blive holdt i højere priser, end han af hensyn til de nye brugere kan give, og at resultatet $i$ almindelighed skal blive en stigning $i$ jordpriserne. Dette sidste vil han dog undgå ved tilbageholdenhed og ved størst mulig stilfærdighed $i$ fremgangsmåden -- derfor har den lokale presse fået et vink om ikke at skrive noget -, han kan udvise, fordi han ikke behøver at købe noget bestemt eller til nogen bestemt tid. - Nu skal han jo orientere sig og se, hvilke tilbud der kommer. Eet er sikkert - den virksombed, han nu indleder, imødeses med de største forventninger. 
22. juni. Der synes ikke at skulle komme til at mangle med tilbud på jord til Niels Frederiksen; i dag har han været ude og se på en hel del; hans interesse samler sig særlig om store arealer ved Sofiedal og i Nørre-Løgum sogn. Jeg har anbefalet ham et par hundrede hektarer af statens jord på flyvepladsen nord for 'øønder; hvis den er tilfredsstillende, kunne han tænke sig, at staten selv opførte bygningerne til en halv snes brug på dette areal. Det ville jo nationalt set have sin gode betydning på dette sted. Jeg kan mærke på Niels Frederiksen, at hans interesse for opgaven er stigende; i eftermiddags, da han på sønderhus" gik fra den ene forhandling til den anden, sagde han henvendt til mig: * Det bliver sgu en stor ejendomshandel, denne her; jeg må nok helst blive her hele sommeren. " - Jeg har kørt nogle ture med ham i omegnen og fortalt ham mest muligt om forholdene; han er ikke upåvirket af, hvad han hører og ser - den vestslesvigske byggeskik er han meget optaget af - og håber, at han, når han nu i næste uge slutter denne sin første, foreløbige orientering her og rejser bort, ikke er helt den samme, som da han kom. Oprettelse af den ofte omtalte jordcentral afviser han aldeles; han vil lade et eventuelt kontor gro frem sammen med opgaven og ønsker iøvrigt at vække mindst mulig opmærksomhed.

24. juni. I går foretog jeg sammen med Niels Frederiksen og hans hustru en tur syd for grænsen. Nic. Svendsen var også med for at vise os en af de tyske "Siedlungen", som Niels Frederiksen meget ønskede at se. Vi beså en sådan ved Lytjenholm i nærheden af Langenhorn; her lå 30 nye brug, som Niels Frederiksen imidlertid ikke blev imponeret af. Vi besøgte en af de nye husmænd, som viste os sit hus fra overst til nederst og fortalte os alt, hvad vi måtte ønske. Niels Frederiksens kritik gik ud på, at bygningerne var alt for dyre, upraktiske og grimme (dårlig villastil), og at brugerne skulle være i besiddelse af en alt for stor begyndelseskapital (ca. $8000 \mathrm{kr}$. - hos os allerhøjst $2000 \mathrm{kr}$.). Vi aflagde besøg ved Dannevirke, hvor Svendsen gjorde den bemærkning, at dette forsvarsværk jo ikke havde kunnet sikre os, men nu måtte vi vente, at Niels Frederiksen byggede os et sikkert værn ved den nye grænse. Denne tanke afviste den nøgterne Niels Frederiksen ikke, men udtalte, at det Dannevirke, som han håbede på at få held til at rejse, nok skulle stå. 


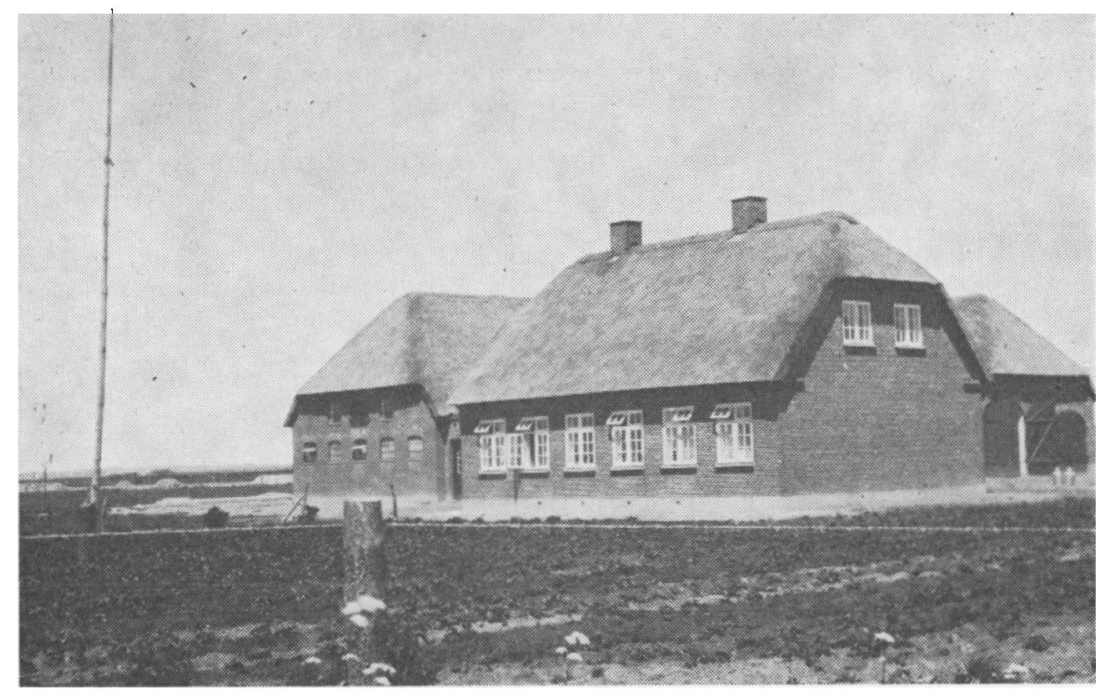

Stråtcekt husmandsbrug i Bjerndrup. Stråtaget er senere blevet udskiftet med ,hårdt" tag.

25. juni. Jeg kunne mærke på Niels Frederiksen i dag, at turen syd på havde øvet sin virkning. Han sagde til mig, at han fik mere og mere lyst til at sætte ind $\mathbf{i}$ det egentlige grænseområde med stor kraft - »Jeg vil gerne vove et panterspring her, om jeg så skulle sætte 2 millioner $\mathrm{kr}$. i jord, og selv om den ikke straks kan udstykkes; den kan ligge hen i nogen tid til græsning som nu. " Han talte atter om, at staten skal bygge nogle mønsterbrug og er meget optaget af de gamle huse og gårde, han har set $i$ Hjerpsted; han glæder sig til at komme til at bygge $\mathbf{i}$ den gamle stil med røde, hårdbrændte sten og rørtag. » Jeg skal bygge noget her, der fuldstændig skal slå dem syd for grænsen«. Jeg glæder mig, hver gang jeg således mærker Niels Frederiksens stigende interesse for opgaven, og jeg har også alvorligt gjort ham opmærksom på, at hans virksomhed kan blive skelsættende i den nationale udvikling i Sønderjylland. Han mærker nok på dem, han kommer i berøring med, at de stiller store forventninger til resultatet af statens 10 millioner kroners indsats.

17. juli. Jeg kom i dag hjem fra et tre ugers ferieophold i Polen og traf Niels Frederiksen sammen med det øvrige jordudvalg på 
»Tønderhus «; han fortalte mig, at der var foretaget en del store indkøb, ialt godt 400 ha., for størstedelen i omegnen af Løgumkloster. Bl. a. er købt en gård i Roost på 100 ha., skønt ejeren og [ikke] mindre hans sønner er anset som ivrige tyskere. Måske vil det vise sig, at de har ret, som siger, at de fleste tyskere vil sælge jord, idet de først og fremmest tænker på pengene.

18. august. Det var opmuntrende at høre den første skoledag efter ferien, i hvilket stort omfang de tyske børn havde været på ferieophold i det gamle land. Særlig glædede det mig at hore en ung pige, som altid synes at have varet ret bevidst $\mathbf{i}$ sin tyskhed, fortælle om sit ferieophold i Silkeborg, hvor hendes store søsters forlovede boede og var fra (udviklingen mod nord!). Hun var fuld af beundring for byen, som hun ikke på nogen måde fandt kunne sammenlignes med Tønder; den var i hendes ojne både større og meget mere tiltrækkende. Hun sluttede derfor med at sige: \$Når min søster nu bliver gift og bosat deroppe, skal jeg nok komme derop igen". Interessant var det også at høre, hvorledes de børn, der havde opholdt sig på landet i Nordslesvig, omtalte det som noget selvfølgeligt, at folkene der udelukkende talte dansk.

13. august. Jeg har i dag fået oplyst, at Landeværnet har et stort tilbud på tyske landejendomme, hvor det ved hjælp af Lånekassen for Sønderjylland er lykkedes at erhverve otte i de »truede egne «. Forklaringen på dette må jo være den, at tyskerne her ikke er i besiddelse af nogen udviklet nationalfølelse, og det kan man vel heller ikke vente, at de skulle være, eftersom de først $\mathrm{i}$ de sidsle ti år er kommet med i nationalitetskampen. Hvis der arbejdes $i$ stilhed - d. v. s. uden alt for mange avisartikler (i »Hejmdal $₫$ !) om udstykningens nationale betydning, kan der måske opnås en hel del. En større tysk gârd, der er brændt i Solderup, er solgt til Den sønderjyske Udstykningsforening, hvilket "Nordschleswigsche Zeitung " naturligvis udtaler sin dybeste beklagelse af. Den tidligere omtalte gård i Roost er solgt til en meget dygtig landmand fra Fyn, Dyrhus ventes solgt til en landmand fra Esbjergkanten (den er overtaget af Handelsbanken), og Niels Skrumsager fortalte mig i søndags, at hjemmetyskeren Otto Johannsen stod $\mathrm{i}$ begreb med at sælge sin gård Nørregård (Norderhof) ved Abild til en ung dygtig mand fra Fyn, 


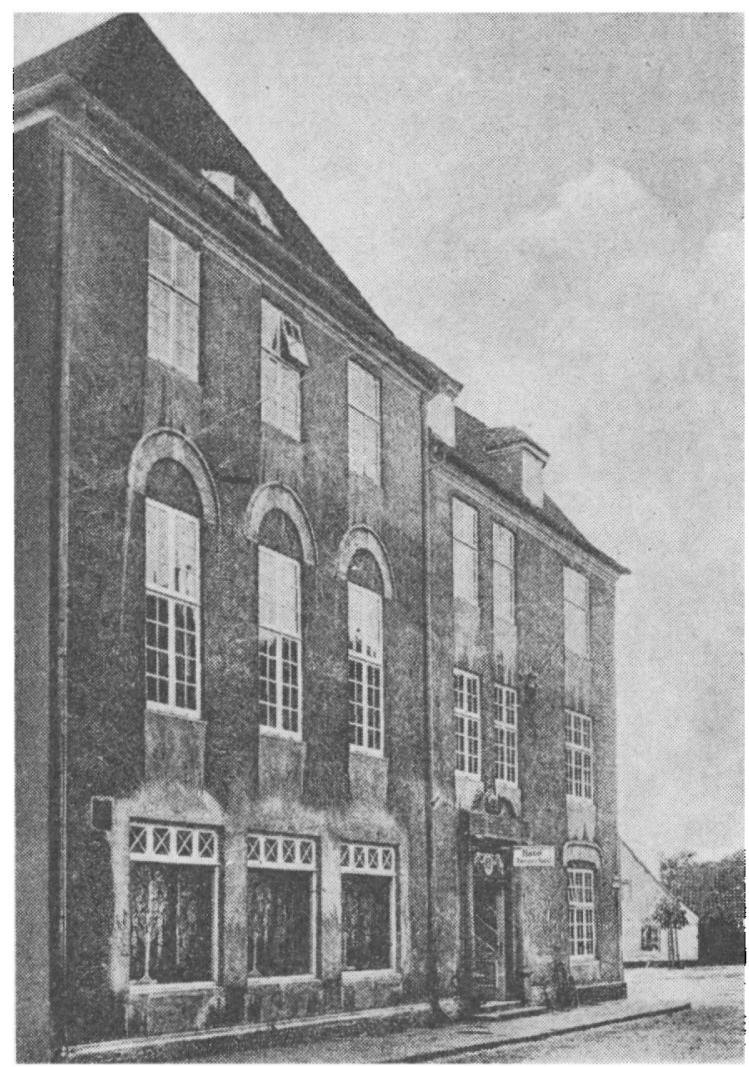

Det danske forsamlingshus „Tonderhus“ $i$ Spikergade

der opholder sig hos N. S. pa Visby Hedegârd. Alt dette er glædeligt, men midt under dette står vi over for den bedrøvelige kendsgerning, at "Tønderhus " igen står foran tvangsauktionen. De nationale foreninger har ikke kunnet støtte os i det nødvendige omfang (og i hvilket vi bestemt mener, at Jefsen Christensen og H. P. Hanssen havde lovet at stotte os, da vi besluttede rekonstrueringen, som vi alene påtog os på grund af disse mænds tilsagn). Vi har måttet meddele kreditforeningen, at vi ikke kan klare juni termin, og på torsdag afholdes på dommerkontoret et møde til fastsættelse af auktionsbetingelser $m$. v. Det er vanskeligt at sige, hvor pinligt dette føles; vi står her overfor en national 
skandale. Tyskerne kan rejse det ene prægtige kulturelle centrum nord og syd for grænsen efter det andet, og vi kan ikke opretholde et dansk forsamlingshus i en by som Tønder, skønt vi med en sum på $15.000 \mathrm{kr}$. kunne have fået gælden nedskrevet fra 115 til 50 tusinde $\mathrm{kr}$. Disse femten tusinde kr. kunne de nationale foreninger ikke skaffe, skønt Grænseforeningen på een gang fornylig har givet dette beløb til et nyt dansk forsamlingshus i Valsbøl (hvor der for få år siden allerede blev bygget en sal $\mathrm{m}$. v. ved Lorenz Jepsens gård) — dette synes mig en fuldkommen misforståelse af, hvor man bør sætte ind i grænselandet. Men der er mange, der synes at have glemt, at der kun var $27 \%$ danske stemmer i Tønder i 1920. Nu er der gået 10 år, og så må alt vel være $i$ orden?! - Men med den slags betragtninger løses sagen jo ikke; vi er blevet enige om at søge auktionen udsat, indtil der foreligger et resultat af vor ansøgning om et statslån på $15.000 \mathrm{kr}$.

15. august. I går aftes afholdt "Tønderhus «' bestyrelse møde; det var om eftermiddagen lykkedes at få tvangsauktionen udsat i nogen tid, forhåbentlig indtil vi får statslånet bevilliget. På denne sag skal der nu arbejdes på kraft, bl. a. ved en henvendelse til statsminister Stauning. På mandag afholdes et større møde af Tønders borgere, hvor der skal gøres rede for stillingen og et forsøg på at tegne en kapital på indtil $1000 \mathrm{kr}$. om året til støtte af "Tønderhus «, nâr gælden kommer ned på 50 tusinde kr.

16. august. Ved henvendelse til jordudvalgets kontor erfarer jeg, at der foreligger ikke så få tilbud om jord fra omegnstyskere, endog fra folk, man skulle forbavses over. Tilbudene kommer enten direkte eller gennem mellemmænd. Men priserne er ofte for store, og derfor bliver der ikke altid noget resultat i første omgang.

17. august. Svendsen kom i dag hjem fra den pædagogiske verdenskonference $i$ Helsingør, under hvilken han havde været $i$ ministeriet og forhandlet med kontorchef Barfoed. Det drejede sig om nogle småbevillinger til vigtige skoleformâl i grænseområdet. $B$. var nu mere end før stiv, bureaukratisk og uforstående over for opgaven hernede og de særlige forhold. - Han gav dette udtryk ved at sige: $\gg \mathrm{Nu}$ er der gået ti år, hr. amtsskolekonsulent, så vi er vel kommet så vidt, at der ikke skal ekstra foranstaltninger til i Sønderjylland ". Hertil svarede Svendsen: "Hr. kontor- 
chef, lad os tale om det om 50 år". - - Dr. Lausten-Thomsen meddelte ved denne lejlighed, at tilskudet fra staten til Tønder danske bibliotek er skåret ned fra 10 til 7 tusinde kroner. Det ene passer godt til det andet - i dette tilfælde er det særlig beklageligt, fordi biblioteket økonomisk set er meget vanskeligt stillet, fordi det kommunale tilskud, hvorefter statstilskudet automatisk fastsættes, på grund af det tyske byrådsflertal er usædvanligt lille - $500 \mathrm{kr}$. mod flere tusinde i lignende byer.

19. august. I går afholdtes et møde med danske borgere i Tønder angående » Tønderhus «. H. Jefsen Christensen var kommet til stede og lovede at støtte vor henvendelse til staten om tilskud i form af et rentefrit lån på $15.000 \mathrm{kr}$. Grev Schack holdt en god tale, hvorefter det blev besluttet blandt den danske befolkning at tegne årlige bidrag til driften af "Tønderhus" $i$ fem år under den forudsætning, at gælden nedskrives til 50 tusinde kroner. Det besluttedes at begynde denne tegning straks, og skønt der kun var ca. 40 personer til stede, tegnedes der dog $700 \mathrm{kr}$. i fem år. Vor højeste forventning var ialt at opnå $1000 \mathrm{kr}$., og når tegningen nu fortsættes blandt de ikke tilstedeværende, vil dette mål formentlig let kunne nås. Dette giver jo straks et lysere syn på den truende situation - nu står det til statsministeren at sørge for resten.

25. august. Rektor West omtalte i dag på en spadseretur de tyske krav om et tysk gymnasium eller eksamensrettigheder for et sådant. Han havde på følelsen, at »Hejmdal " og altså H. P. Hanssen var ved at svinge i dette spørgsmål til fordel for kravenes opfyldelse. Jeg fremhævede som min mening, at det var naturligt, om Danmark sagde: »Vi kunne i og for sig godt opfylde jeres ønsker, hvis forholdet var det, at I ikke kræver grænsen flyttet, men da I gør det, vil vi ikke styrke jer ved at give nye betydningsfulde rettigheder. Man understøtter nemlig ikke sine egne modstandere, og I er statens modstandere i dens nuværende udstrækning ". - Jeg fremhævede dog endvidere, at jeg troede, at den politiske udvikling i Europa gjorde det nødvendigt at opfylde de tyske skolekrav, og at det også politisk set var klogt at gøre det for derved at berøve tyskerne deres væsentligste agitationsstof. Desuden: at Danmark kunne føle sig stærk nok til at gøre denne indrømmelse, fordi det tyske mindretal $\mathrm{i}$ ikke ringe 
grad formentlig vil hensmuldre ved fraflytning, ved blandede giftermål etc. og fordi der i tidens løb vil bosætte sig så mange folk nord fra i dette folkefattige land, at det tyske mindretal vil blive indkapslet og forholdsvis formindsket. Rektor West syntes bedst om det første synspunkt.

1. september. Jeg kom i går hjem fra en rejse til København, hvor amtsfuldmægtig Florander og jeg blev modtaget af statsminister Stauning, hvem vi forelagde onsket om et statslån på $15.000 \mathrm{kr}$. til rekonstrueringen af "Tønderhus". H. Jefsen Christensen og J. P. Nielsen var også tilstede. Efter nogen talen frem og tilbage udtalte statsministeren: »Ja, De må jo have de pengex, og sagde, at vi kunne sige til kreditforeningen, at det var sandsynligt, at vi fik lånet; samtidig betonede ministeren imidlertid, at det jo til syvende og sidst var finansudvalget, det kom an på, hvorfor han naturligvis ikke kunne sige bestemt, at vi fik det. Afgørelsen kan ikke ventes før i oktober, når rigsdagen træder sammen. - Ved en efterfølgende frokost kom jeg til at tale med J. P. Nielsen om forskellige grænseproblemer og spurgte ham, om han ikke syntes, at det var naturligt, om man fra dansk side ved de kommende forhandlinger i rigsdagen om de tyske skolekrav sagde til tyskerne, at vi ikke kunne give dem eksamensret for deres højere skoler og andre nye rettigheder, så længe de gang på gang erklærede, at grænsen skal flyttes mod nord. J.P. Nielsen sagde hertil, at det var et standpunkt, han godt kunne tænke sig, at man ville hævde. - Senere talte jeg med justitsminister Zahle, hvem jeg gjorde opmærksom på den danske grænsebevogtnings smålighed og pedanteri. Jeg talte også med indenrigsminister Dahlgaard om forskellige sønderjyske anliggender, bl. a. Det kongelige Teater's gæstespil hernede, som nu sikkert bliver til alvor.

12. september. Jordlovsudvalget har i dag købt Adelvad, som ejes af en indvandret tysker ved navn Riewe. Arealet udgør over 150 ha. Dette køb må anses for det glædeligste resultat, der hidtil er nået. "Jeg ved nok, at jeg bliver slæbt gennem den tyske avis «, sagde Riewe, da handelen var sluttet.

21. september. I eftermiddags holdtes det årlige fortrolige møde i »Slogsherredshus * i Bylderup. Schmidt, Vojensgård, indledte en forhandling om jordspørgsmål; han var af politiske grunde noget 
betænkelig ved de store jordkøb fra statens side. Når den opkøbte jord skulle sælges til nye brugere, ville han meget advare mod at anvende 4. oktober loven af 1919 , som han - skønt tilhørende Radikale Venstre - mente ville skabe en ufri bondestand, »og vi må netop have frihed, hvis vi skal fastholde grænselandets jord ". - Jeg skal gengive enkelte udtalelser. Hans Andersen, Kongsbjerg: Vi behøver i øjeblikket ikke at se så mørkt på jordspørgsmâlet - Landeværnet mærker ikke til noget stærkt angreb på jorden fra tysk side; men danskerne er i fremgang, idet der jævnlig går en tysk ejendom over på danske hænder. Men den store folkemangel kræver mange nye kræfter - der må og skal komme folk nordfra herned, »men jeg tror ikke, vi skal importere førere; vi skal opsuge dem, der kommer herned til os, så at de kan være med i det grænseværn, som befolkningen her skal yde. Vi skal have sådanne, der vil gå op i folket, som skal være et grænsefolk ".

Folketingsmand Chr. Ernst Christensen: Vi har jord nok penge nok - men ikke folk nok! Men det er glædeligt at se, hvorledes folk begynder at finde herned. Vi mærker det på Als, hvorledes fynboerne nu bosætter sig hos os, og nord fra ved den gamle grænse sker der ligeledes en tilflytning. Jordlovsudvalget har nu opkøbt ca. 1000 ha jord, som kommer til udstykning $i$ foråret 1930.

Refslund Poulsen: Jeg kunne onske lidt mere fart i udstykningen og er aldeles ikke bange for "føreremner». Den bliver fører, som befolkningen gør dertil.

Peter Gad: Det er ønskeligt at få en stærk tilgang af unge dygtige landmænd nord fra. - Jo flere, jo bedre! Men vi skal helst have folk, som har penge.

H. P. Hanssen sluttede mødet med bl. a. at sige, at når man for tiden ikke kunne sige, at der foregik noget angreb på jorden, var det, fordi tyskerne onskede et pusterum, men man måtte regne med, at de nok skulle skaffe sig penge til jordkampen i grænseområdet.

23. september. Efter indvielsen af pumpestationen ved Lægan holdtes der en fest i kroen; alle tilstedeværende tyskere med undtagelse af redaktør Fr. Andresen holdt deres taler på dansk, og stem ningen var udmærket; som arbejdet skrider frem, bliver også 
tyskerne mere og mere veniigtsindede over for afvandingen. Noget af det samme gav Andresen udtryk for i sin tale, samtidig med, at han åbent udtalte, at han af politiske grunde egentlig måtte være en modslander deraf, fordi man jo som en af følgerne inătte regne med en dansk tilvandring til egnen. - Man mærker stadig, hvorledes folk således regner med en forøgelse af befolkningen omkring Tønder.

26. september. På kongens fødselsdag var der $\mathrm{i}$ det dejligste september solskin hejst ualmindelig mange flag - for første gang også på fhv. sagfører Todsens hus, der jo nu tilhører staten og benyttes af Jordlovsudvalget. Tiderne ændrer sig! — Det var dagens sensation i Tønder.

10. oktober. Efterårsferien har jeg tilbragt i København, hvor jeg havde nogle sager at ordne. Først Tønderhus «! Statsministeren havde jo stillet os $15.000 \mathrm{kr}$. i udsigt, og på grundlag af dette tal var der truffet aftale med kredit- og hypothekforeningen om en gældsnedskrivning fra 115 til 50 tusinde kr. Det var derfor meget ubelejligt, at der meddeltes os fra statsministeriet, at der kun kunne forventes bevilget 10 tusinde kr. Da jeg alligevel skulle til partimøde i København, skulle jeg søge sagen ordnet, og det lykkedes at få pengene, men rigtignok efter et næsten 2 dages ophold i rigsdagsbygningen og megen forhandling med rigsdagsmænd og ministre. Disse sidste mente, at "Tønderhus " meget hellere måtte gå til tvangsauktion, hvor vi da kunne købe det billigt, og så ville staten meget hellere give os penge til restaurering end til kreditforeningen til frivillig akkord. I et nyt ministermøde om sagen bøjede man sig imidlertid for det synspunkt, at man af nationale grunde ikke kan have en tvangsauktion over et dansk forsamlingshus i Tønder. De $15.000 \mathrm{kr}$. blev da vedtaget, og dermed er der sikret en så stærk gældsnedskrivning, at "Tønderhus" kan holdes. - Samtidig henvendte jeg mig til sagfører Mandal Berthelsen angående en mindre ombygning og restaurering af "Tønderhus". Han viser dette spørgsmål interesse og vil arbejde hen til, at vi kunne få pengene - ca. 5 tusinde kr. af Dybbøldagen.

Med Det radikale Venstre's ordfører i sagen angående de tyske skolekrav, fhv. kirkeminister, pastor Povlsen, havde jeg en længere samtale, bl. a. foranlediget ved, at undervisningsministe- 
riet havde udarbejdet udkast til en ændring af den sønderjyske skolelov. Endringerne er bl. a. præget af ministerialembedsmændenes lyst til at komme bort fra særlige bestemmelser $i$ den sønderjyske skolelov, særlig de små skolekommissioner. Desuden skulle de betyde en indrømmelse til »Herning-overenskomsten" og indeholdt derfor bestemmelsen, at tyskerne skal være repræsenteret $i$ alle skolekommissioner, inden for hvis område der findes tyske skoler. Da forholdene som bekendt er det, at tyskerne allerede har en sådan repræsentation, og at deres gamle krav er særlige tyske skolekommissioner, kan vi jo ikke fra den kant vente nogen tak for de foreslåede »indrømmelser", og da det må anses for uklogt, at staten allerede nu begynder at røre ved vor skoleordning, fremhævede jeg overfor Th. Povlsen meget stærkt, at der ikke fra regeringens side burde fremsættes ændringer, som man ganske kunne overlade til pastor Schmidt at stille forslag om. Mine synspunkter tiltrådıe pastor Povlsen fuldtud; han var ubehagelig berørt af, at der forelå de omtalte regeringsplaner, som han gennem udenrigsminister dr. Munch vil søge hindret. Vi talte også om eksamensret for højere tyske gymnasieskoler; jeg fremhævede, at Danmark af saglige grunde godt kunne opfylde dette ønske, men ikke af politiske, idet jeg påpegede, at tyskerne ikke burde tilstås en sådan indrømmelse samtidig med, at de demonstrativt har sat kravet om grænseflytning i spidsen af deres program og taler herom ved enhver lejlighed. "Man kan ikke den ene dag forlange statens grænser rykket tilbage og den næste dag forlange store, kulturelle indrømmelser af den samme stat. En anerkendelse af grænsen må være grundlaget for opfyldelsen af nye onsker. I hvert fald må vi forlange, at førerne holder op med offentligt at tale om grænseflytning ". Pastor Povlsen syntes også at dele dette synspunkt. Vi var enige om, at kravet om særlige tyske skolekommissioner burde opfyldes, fordi vi begge mente, at dette er en naturlig konsekvens af det synspunkt, at hver skole bør have sin egen kommission, således som det allerede er tilfældet på de steder, hvor skolen ikke er delt i en dansk og en tysk afdeling.

I rigsdagen traf jeg folketingsmand J. P. Nielsen, socialdemokrat, (Dynt, Broager), der bl. a. fortalte, at han for nogen tid siden havde været hos den tyske gesandt von Hassel (Tirpitz's 
svigersøn), der åbent havde sagt, at han ikke kunne indse, hvilken interesse Tyskland skulle have $i$ at opretholde sit mindretal $i$ Nordslesvig, da det jo var et ganske uægte mindretal. - J. P. Nielsen mente, at det stadig blev vanskeligere for tyskerne at fastholde de tyske arbejderkredse, for hvilke det mere og mere gik op, dels at det tyske mindretal er reaktionært ledet - særlig i forhold til "Republikken Tyskland " - dels at det er urimeligt, at dansktalende folk sender deres børn i tyske skoler. Han fremhævede stærkt, at undervisningen burde ske på grundlag af modersmålet, og at tyskerne ikke burde have nye indrømmelser hverken med hensyn til højere skoler eller særlige tyske skolekommissioner. Dette standpunkt er jo interessant, da socialdemokraterne ifølge "Herning-overenskomsten " $i$ hvert fald til dels er bundet til at opfylde de tyske skolekrav.

22. oktober. Spørgsmålet om en ny dansk folkeskole i Tønder er igen aktuelt, efter at ministeriet har udtalt, at byen efter 1. april 1930 selv må drage omsorg for undervisning af antallet af børn over 250 , som nu undervises i seminariets øvelsesskole. Om denne sag afholdtes $i$ går et fællesmøde mellem Tønder amts skoledirektion og byrådets skoleudvalg. Desuden var seminarieforstander Albeck tilstede ved mødet, der under grev Schack's ledelse afholdtes på amtshuset. Borgmester Thomsen udtalte, at han ved samtale med seminarieforstanderen havde fået det indtryk, at der ikke kunne indrettes flere lokaler på seminariet, hvorfor han mente, atl byen selv skulle drage omsorg for en skole, som han mente burde ligge $i$ den vestlige del af byen, hvor der ingen skoler findes, og hvor de fleste danske bor. Han havde tænkt sig hertil at anvende den tomme telegrafbygning (tidl. tyske rigsbank), hvis staten ville stille den til rådighed. Dette standpunkt gav de tre skoledirektionsmedlemmer principiel tilslutning, idet direktionen ligeledes havde den opfattelse, at seminariet ikke kunne beholde bornene. Svendsen meddelte, at seminarieforstanderen, der først senere kom til stede ved forhandlingen, havde anmodet ham om snarest muligt at blive fri for de klasser, der lå ud over det antal (7 a 8), der ligger over et almindeligt købstadsskole-system. Da forstanderen kom til stede, skete der imidlertid det mærkelige, at han meget bestemt udtalte det onske at beholde alle danske børn på seminariet, idet han mente, at en 
staldbygning mellem forstanderboligen og seminariet kunne ombygges og indrettes til klasseværelser. Dette standpunkt virkede som en pinlig modsætning til Svendsens udtalelser; da S. selv gjorde opmærksom derpå, udtalte forstanderen, at han ikke før havde tænkt på en ombygning af den nævnte stald. På grevens direkte spørgsmål udtalte jeg, at en ny dansk skole burde ligge i den vestlige bydel, fordi hele udviklingen går $\mathrm{i}$ den retning og særlig under henvisning til den foreslåede indlemmelse af den hertil grænsende del af landsognet. Men byen måtte i denne sag også tage økonomiske hensyn, og da forstanderens plan måske blev den billigste, måtte vi formentlig forbeholde os vor stilling, indtil planen forelå udarbejdet. Til dette standpunkt sluttede sig det ovrige skoleudvalg. - - Jeg er ikke i tvivl om, at det også af nationale grunde ville være langt det fordelagtigste at lægge skolen mod vest, netop fordi de andre skoler alle ligger inde $\mathbf{i}$ byen. Mange af de mindre nationalt interesserede tyskere ville da fortrinsvis vælge en sådan dansk skole, idet de sikkert mere vil tage hensyn til den kortere skolevej end til skolesproget. Stærkere er modsætningerne nu een gang ikke i ret vide kredse. Men seminarieforstanderen er en herskelysten natur, der gerne vil regere over mest muligt.

24. oktober. To tidligere elever fra den tyske skole . . . har i dette efterår begyndt et tre vintres dagkursus på håndværkerskolen i Odense. Jeg har haft breve fra dem, og de er glade for skolen. Moderen til den ene . . . fortalte mig, at de havde en søn boende i Hjørring, hvor han var bager, gift med en pige fra Alborg, som han havde lært at kende i sin soldatertid der. En datter var gift og bosiddende i København, og moderen håbede, at denne søn . . . nu måtte få arbejde på Fyn om sommeren i de tre år, uddannelsen i Odense stod på. Jeg tror, man tør sige, at denne families forhold udgør et interessant og karakteristisk udsnit af den almindelige udvikling hernede $i$ retning af orientering mod nord...

25. oktober. I en af skolens øverste klasser har jeg en elev $i$ dansk ...., søn af en ret tysk håndværker. Han er ikke meget begavet - omend flink og villig - men da han kun taler tysk hjemme, har han haft store vanskeligheder i dansk. Men jeg har ikke kunnet undlade at mærke, at hans forståelse af dansk $i$ 
enhver henseende har været $i$ livlig udvikling $i$ den sidste tid. I dag kunne han således ene af klassens elever forklare, at »das wurde abgelehnt " ikke alene kan oversættes ved: »det blev afslået « men også ved: »det blev afvist «. Jeg spurgte ham da, hvoraf det kom, at han nu forstod alting, hvortil han svarede, at det var, fordi de nu hjemme havde en svend, som var fra Fyn, og ham talte han meget med - - for han er så flink — og så taler vi dansk «. - Atter her et lille billede på, hvorledes det danske trænger sig frem på alle måder, hvorledes det praktiske livs danske former bryder sig sin vej på tværs af alle tyske organisationsrammer og arbejde for millionbeløb fra den prøjsiske stat. Jeg tror også, at det er ved at blive tyskerne klart, at den danske påvirkning er overvældende stærk og uundgåelig — den er som en stadig stille rindende vandstrøm ned over Sønderjylland. Der afsættes uvægerligt et lag af indtryk $i$ sindene, hvis indhold således bliver mere og mere danskpræget, på samme tid som de tysksindede mere og mere mister deres virkelige kendskab til Tyskland, og de opvoksende unge tyske slet ikke kender Tyskland, men kun levemåde og statsform i Danmark. Det omtaltes også for nogen tid siden $i$ den tyske avis "Nordschleswigsche Zeitung «, hvorledes endog det tyske sprog blev påvirket af det danske; ord som byråd, sogneråd, ejendomsskyld, dommer, politimester o.s. v. bruges uden videre i tysk tale, således at vore landsmænd fra Tyskland forbavses, når de hører os «. For ovennævnte $o$. lg. begreber kender de unge tyske efterhånden alene de danske ord og bruger dem i deres iøvrigt tyske tale. Det er heller ikke sjældent, at tyskerne $i$ byrådet bruger former som: »das wurde aber genægtet " eller f. eks. "gedrøftet o. lg. Denne udvikling er farlig for tyskerne, fordi den foregår så umærkeligt. Jo længere tiden går, des bedre forstår man, hvor uhyre et mindretal som det tyske i Nordslesvig er udsat for svækkelse og påvirkning udefra; ganske særlig fordi afstanden til den dem omgivende danske befolkning, kultur, sæder og skikke er så ringe - ja ofte ikke til stede. Det galder blot for os om at lade udviklingen foregå i ro, thi kun under modstand har tyskerne mulighed for at oparbejde en levende reaktion mod det danske. Denne ro kan vi heldigvis sige er til stede; kun pressen lader noget tilbage at ønske. Det er ikke altid *Vestslesvigsk Tidende" og "Hejmdal * 
viser forståelse for den tanke, at der skal ro til, hvis de to befolkningsdele skal vokse sammen. Det nationale spørgsmål, tyskernes brug af det danske sprog, jordspørgsmålet o. s. v. bør ikke hver dag tages op til droftelse og beskuelse. Derved vækker vi let mange af dem, der nu sover og arbejder sig ind til Danmark.

26. oktober. Et par træk fra livet $i$ den tyske skole: en 11 års pige ... fortæller mig glædestrålende, at hun nu kender sangen "Se Norges blomsterdal", som vi havde talt om. "Hvor har du lært den? " — "Den har jeg lært af vor tjenestepige, hun er fra Fyn, og hun lærer mig så mange danske sange». En anden pige ... rejser sig med en gammel »blå sangbog « i hånden og siger: " Heri er så mange konne sange, og min moder siger, at da hun var ung, sang de altid $i$ den om aftenen, og så kom politiet sommetider ind, for det måtte de ikke". Man forstår, at det danske også har visse prioriteter $i$ den tyske skoles rækker.

27. oktober. I går afholdt en mindre kreds fra hele landsdelen et møde i Åbenrå angående det sønderjyske teaterspørgsmål. Herunder påpegede repræsentanter fra Tønder og omegn, at et væsentligt antal af de kommende teaterforestillinger måtte være offentlige, for at tyskerne, son gerne går i dansk teater, ikke skal blive udelukket. Hvis der kun bliver foreningsforestillinger, udelukker vi jo hele den befolkningsdel, som netop vi er interesseret i kommer under dansk påvirkning, når det sker ad frivillighedens vej. Disse synspunkter blev ikke forstået af deltagerne fra den øvrige landsdel - end ikke af H. P. Hanssen, der stærkt gav sin tilslutning til, at der kun skulle være tale om foreningsforestillinger, dels for at spare forlystelsesskatten, dels for at hverve flest mulige medlemmer til de danske foreninger. Vi hævdede, at dette sidste ikke var målet, men kun et middel og derfor ikke afgørende her. Det hjalp ikke! Det blev her som ved andre lejligheder klart, at tankegangen med hensyn til vort forhold til tyskerne er meget forskellig i Tønder og Haderslev, hvor man efterhånden synes at regne mindre og mindre med det nationale problem, naturligvis fordi tyskerne er så forholdsvis få. I Tønder er vi ved at blive noget for os selv - det "slesvigske" er nok her mest udpræget, og mange af os, der er kommet nord fra, står vist i nogen grad for at blive opsuget. Måske møder vi slesvigerne på halvvejen i opsugningsprocessen. Jeg kender flere tilfælde på, 
at børn, der er født hernede af kongerigske familier, taler sønderjysk og også på anden måde er præget af forholdene her.

10. november. Den 30. oktober holdtes et fortroligt møde på Rødding Højskole. Biskop Ammundsen indledede en forhandling om Det nationale og det sociale . I forhandlingen deltog den socialdemokratiske folketingsmand J. P. Nielsen. Højskoleforstander Terkelsen, ("Danebod") udkastede da det spørgsmål "Hvor går grænseegnens ungdom hen? Modl nord eller syd? * Foranlediget derved tog jeg ordet og svarede: Mod nord! Jeg henviste til, at jeg $\mathrm{i}$ min 10 års virksomhed ved Tønder tyske borgerskole vel havde haft at gøre med ca. 500 unge tyske, der i den tid var gået ud af skolen. Disse unge, sagde jeg, er ikke mere i Tønder, kun $i$ ringe antal sydpå, men $i$ store tal spredt over hele kongeriget, hvorfra de fleste sikkert aldrig vender tilbage til grænseområdet, bl. a. fordi de føler sig mere fritstillet på et sted, lvor der ingen nationale modsætningsforhold findes. Jeg nævnede en del eksempler herpå. Disse forhold, som jeg tidligere har omlalt på dette sted, vakte både forbavselse og glæde, og der blev stillet mig mange spørgsmål $i$ den anledning. Dette førte mig til nogle dage senere at foretage en nærmere undersøgelse af dette forhold i skolens øverste klasse, hvor de fleste drenge har brødre, der før havde gået $\mathrm{i}$ skole hos mig. Ligesom tilfældigt spurgte jeg, hvor er din store broder Peter henne? Din broder Jens? o.s. v. Og uvægerligt faldt svarene, han er på Lolland, i Hørved på Sjælland, i Ruds Vedby, i København, Kalundborg o. s. v. Når jeg så spurgte, om broderen nu ikke lavede mange fejl, når han skrev tysk, fik jeg ligeså uvægerligt svaret: $\gg$ Nu skriver han kun dansk *. Med stolthed fremviste [en dreng, der har en broder], som er elev på Odense tekniske skole, to store fotografier af skolen. Alle drengene så beundrende til. En udbrød da: "Jeg tror nu alligevel, at Teknologisk Institut $i$ København er større — kender du dertil? « spurgte jeg. "Der er min broder uddannet som skorstensfejer; ham, der nu er i Kalundborgl * Min broder har nu gjort to rejser med $\$$ Frederik den Ottende , faldt en anden ind, shan skal være kok*. * Det var ellers et fint skib at komme ud med! « bemærkede jeg, og en dreng tilføjede: sDet er det største skib, vi har — —Vi har" — i disse ord ligger jo hele denne drengs indstilling over for Danmark. For mig at se befin- 
der store dele af den tyske ungdom sig således som på en jæunt rindende strøm, der munder ud $\mathbf{i}$ »danske farvande ".

15. november. Ved en sammenkomst af lærere ved Tønder tekniske skole brugte det tyske byrådsmedlem, maler Johannsen vendingen »og så blev han så gal som en tysker". "Hvad siger De? ", kom det fra lærer Gläser (tysk). »Ja, hvad det siger man jo«, lød svaret. Aber dass müssen Sie in der Stadtvertretung nicht sagen ‘, lød Gläsers godmodige formaning.

I Østergade bor over for hinanden den danske broderihandlerske, frk. Jacobsen og den tyske guldsmedeenke, fru Bødewadt, der driver sin afdøde mands forretning. Frk. Jacobsen fortalte mig forleden, at fru Bødewadt ofte kommer ind og handler hos hende og altid taler tysk, og da hun er kunde, taler frk. Jacobsen også tysk til hende. Men når så hun gâr over og handler hos fru Bødewadt, taler hun dansk, og da hun så er kunde, taler fru Bødewadt også dansk til hende. Således kan livet forme sig i en by med sproglige forhold som $\mathrm{i}$ Tønder.

4. december. I morgen kom det sønderjyske jordlovsudvalg igen til byen angående udstykningsarbejdet. Jeg er spændt på resultatet denne gang; det skal nemlig endelig afgøres, om et tilbud på en stor gârd i Udbjerg — ... - skal modtages. Det er to gange afvist; det kan altså siges, at der sættes alt ind på at få fat på tyskernes jord - ejeren er nemlig tysk - og egentlig er det jo - politisk set - klogt, at vi i flere tilfælde kan påvise det. Imidlertid må det jo siges at være særlig ønskeligt at skomme ind " i Udbjerg, hvor danskhedens svage stilling kendetegnes ved, at der ingen selvstændig dansk skole findes. Da det endvidere forlyder fra god kilde, at een — måske to - af . . naboer også vil sælge til Jordlovsudvalget, hvis han gør, har jeg for nogen tid siden skrevet til Niels Frederiksen og bedt ham om at gå med til købet i Udbjerg, hvis det er på nogen måde forsvarligt. Nu skal vi altså se, hvad der kommer ud af det. Niels Frederiksen har hidtil været betænkelig ved at købe marskjord til udstykning.

Ved byrådsmødet den 29 . f. m. rejste socialdemokraten, remisearbejder Christensen (kongerigsk) sprogspørgsmålet. Christensen, der er den bortrejste red. Petersens efterfølger, har hidtil deltaget i en række byrådsmøder uden at tage del i forhandlinger. I ovennævnte møde udtalte han: Det er nu efterhånden blevet 
mig klart, at jeg ikke kan forstå den del af forhandlingerne, der foregår på tysk. Jeg må derfor bede borgmesteren om også at fremsætte sine forslag på dansk. Dette siger jeg ikke for at irritere nogen - jeg kender nok forholdene her $i$ byen -- men jeg må vide, hvad jeg stemmer om. Naturligvis kan jeg heller ikke forstå alt, hvad de øvrige tysktalende herrer siger; men det må jeg jo finde mig i *. Disse bemærkninger blev fremsat på en rolig og meget tiltalende måde, der ikke forstyrrede den gode fred og ro. Borgmesteren udtalte, at Christensens ønske var fuldt ud rimeligt, hvorfor han selvfølgelig ville respektere det. Skulle han engang glemme at oversætte et forslag til dansk, ville han blot bede Christensen gøre ham opmærksom derpå. Denne forhandling viser, at der kan nås ret vidt selv $i$ dette delikate spørgsmål ved en rolig fremgangsmåde. - Christensens henstilling kan godt lidt efter lidt fore med sig, at borgmesteren også bruger dansk foruden ved forslagenes fremsættelse.

7. december. Niels Frederiksen fortalte $i$ går, at der nu er projekteret 108 nye husmandsbrug til opførelse i foråret på den jord, som det sønderjyske jordlovsudvalg indtil nu har købt. Der melder sig nu heldigvis rigeligt med kvalificerede ansøgere både fra det gamle land og hernede fra. Til det næunte antal nye brug er derimod kun siger og skriver to (2) kvalificerede tyske ansøgere; så foreløbig synes der ikke at være nogen fare for, at de unge tyske i stort omfang skulle være forsynet med kapital syd fra, således at de ville udgare et uforholdsmæssigt stort antal af de kvalificerede ansøgere. Nogle foruroligende rygter $i$ den retning var for nogen tid siden fremme $i$ pressen.

8. december. Ved et besøg hos H. P. Hanssen i går kom vi til at tale om pastor Schmidts rigsdagstale $\mathrm{i}$ anledning af den sønderjyske udstykningslov. Hanssen fortalte da, at dr. Lorenz Christensen, da pastor Schmidt ved behandling af et sønderjysk forslag for et par år siden havde påstået, at tyske ansøgere blev tilsidesat af Hypotheklånefondet, havde skrevet til ham og bebrejdet ham, at han ikke nævnede navnene på de tilsidesatte i stedet for at klage i almindelighed. Pastor Schmidt havde da svaret, at der forelå to bestemte tilfælde, som imidlertid ikke var egnede til at fremdrages; vedkommende havde fået pengehjælp af »Vogelgesang * - men da de stod til restance med skat og erholdt fattig- 
hjælp, havde deres hjemkommuner lagt beslag på pengene. Tilfældene var derfor ikke så heldige at anføre. Hammerich var imidlertid blevet ilde berørt af angrebet og havde meddelt pastor Schmidt, at Hypotheklånefondets kontor og arkiv til enhver tid stod til hans rådighed, således at han kunne foretage sine undersøgelser. Først et par uger efter svarede pastor Schmidt, at han endnu ikke havde haft lejlighed til at benytte sig af tilbudet, men at han senere ville komme. Han kom imidlertid aldrig. Det samme tilbud blev på given foranledning også givet dr. Lorenz Christensen, som kom til stede og intet som helst fandt til støtte for pastor Schmidts påstand i rigsdagen. Tværtimod så han, at en søn af den meget omtalte tyske lærer Hans Olde Petersen havde fået lån til en jordfordelingsgård.

Hanssen fortalte ved samme lejlighed, at der for nogen tid siden var rettet en henvendelse til de fire politiske partier om hjælp til »Flensborg Avis «. Det var ikke blevet til noget, da socialdemokraterne stillede sig modvillige, formentlig fordi bladet fremdeles indtager et ensidigt partipolitisk standpunkt samtidig med, at det foregiver at være neutralt $i$ dansk indrepolitik, hvilket det naturligvis skulle være, når det vil samle alle kredse til støtte. På et vist tidspunkt så det ud til, at bladet måtte standse den 1 . januar 1930.

\section{0}

1. januar. Der foreligger flere meddelelser fra Slogs herred og Tinglev om, at stadig flere unge tyskere kommer til stede ved danske møder. Den kendte tyske fører I. B. Jepsen i Tinglev har dertil sagt: "Vore unge må hellere være der end i kroen". Linjerne udviskes allerede nu, 10 år efter .

2. februar. Ved en sammenkomst hos $\mathrm{H}$. V. Clausen fortalte dr. Lorenz Christensen om forhandlingerne $\mathrm{i}$ "Schleswig-Holsteiner Bund " angående de forelagte tyske skolekrav. Han hævdede, at det $i$ virkeligheden var de mådeholdne tyskere, der havde foranlediget disse positive forslag fremsat, mens de uforsonlige hidtil havde holdt sådanne opfyldelige krav tilbage og også onskede det nu; thi hvis kravene om særlige tyske skolekommissioner, tysk eksamensret for et privatgymnasium o.s.v. blev opfyldt, swo bleibt dann die Protestgrundlagec havde man meget beteg- 
nende tilråbt pastor Schmidt. - De uforsonlige onsker, at der fordres autonomi. Jeg har sagt til pastor Povlsen og dr. Munch, at man skulle tilbyde det. Pastor Schmidt ville komme i stor forlegenhed ved tilbud om en gave, der ville være farlig for tyskerne. For os ville en sådan ordning intet offer betyde.

14. marts. I den tyske skole holdtes som i alle folkeskoler en ministeriel prøve i skriftlig dansk og regning. De tyske børn var meget optaget af sagen, som de tog på med både alvor og spænding. Atter et bevis på, hvorledes de fleste tyskere er indstillet på en positiv og venlig måde overfor, hvad der er dansk.

15. marts. Ved nyindmeldelse af skolebørn er der indmeldt langt flere (også forholdsvis) til de danske afdelinger i Rens og Jyndevad end til de tyske.

8. april. I går kom jeg forbi en datter af den tidligere - meget tyske - amtsforstander H. C. . . . Hun karte med sit lille barn i vogn, og idet jeg gik forbi hende, bøjede hun sig ned over barnet og sagde på udmærket dansk: "Kan du ligge stille med dit lille hoved «. 2. generation opdrages altså på dansk.

14. juni. Ved et møde i en mindre kreds, hvoriblandt var landstingsmand $\mathrm{H}$. Jefsen Christensen, blev jeg opfordret til at overtage det ærefulde hverv som skoleforeningens kasserer. Jeg henviste til, at jeg dårligt kunne få tid dertil, men lovede dog at sige ja, hvis jeg derved ikke ville skabe mig store vanskeligheder i mit arbejde på den tyske skole. For at få dette konstateret udbad jeg mig en samtale med overlærer Hansen sammen med lærerne $H$. P. Hansen og $\mathrm{O}$. Gläser. Vi talte længe frem og tilbage om det, jeg ønskede at få at vide, om man i tyske forældrekredse ville se med mistillid på mig, hvis jeg tog mod opfordringen. Mine kollegers svar gik i den retning, og jeg besluttede da ikke at overtage den tilbudte stilling, der iøvrigt lønnes med $1200 \mathrm{kr}$., hvilket jeg naturligvis ikke havde oplyst mine kolleger om. Deres svar har således for så vidt ikke været påvirket af den indtægtsforøgelse, som de vel $i$ og for sig gerne så, at jeg fik.

9. september. Redaktør Filskov læste i dag for mig et fortroligt brev fra Flensborg, hvoraf det fremgår, at der forhandles om, at danske skibsværfter skulle overtage Flensborg-Værftet. En sådan ordning ville uvilkårligt fả national betydning; men jeg tror nu ikke derpå. De danske skibsværfter har ganske vist gode tider, 
men vanskelighederne kan også komme til dem, så de skal være glade, om de kan klare sig selv.

11. november. Jordlovsudvalget har nu endelig købt »StamJohannes' " gård i Østerby. Dette er en glædelig efterretning, for de tyske slægtninge havde stærkt regnet med at skulle overtage gården, hvilket ville have betydet en ubehagelig forggelse af tyskeriet i Østerby, der ikke er uden betydning.

\section{3}

1. januar. For et par dage siden modtog jeg et brev fra indenrigsminister Dahlgaard, der takkede mig for mit arbejde for partiet, hvis kandidat jeg havde været ved valget d. 17. 11. 1932, og for mit arbejde hernede i det hele taget. Jeg svarede derpå bl. a. følgende:

"Men nâr der er kommet så meget positivt ud af dette, skyldes det $i$ høj grad regeringen og først og fremmest Dem. På årets første dag vil jeg derfor bringe Dem en varm tak derfor. De må ikke tvivle om, at jeg ofte har været betænkelig ved i så høj grad at lægge beslag på Deres opmærksomhed i en travl tid. Men jeg har gjort det i tillid til Deres udtalelse til mig kort tid efter regeringens dannelse, om at jeg hos Dem altid ville finde forståelse for spørgsmål af grænsepolitisk interesse — af betydning for styrkelse af den grænse, som de to regerinspartier ønskede fremfor enhver anden. - At fæstne vor nuværende stilling i Sydslesvig synes mig - er vort slægtleds store historiske opgave, og når love og forhandlinger om krise o. lg. er blegnet $i$ bevidstheden, vil historien melde om, hvordan denne generation og især regeringen tog på vor store rigsopgave, som tidligere slægtled havde længtes efter at få overdraget. - Som Danmark løser opgaven, er den smuk, fordi den uvægerlig har forsoning til følge til eksempel for hele verden - og den er ikke uoverkommelig; thi vi har i den grad de naturlige forudsætninger på vor side, at vi i hvert fald slet ikke behøver at sætte ind med kunstige midler. - Vi skal blot bo og bygge $i$ landet. For chauvinisme er der ingen plads, men efter Danmarks store tab gennem tiderne er det berettiget, at vi ved vor nye grænse siger, nu går vi ikke mere tilbage, - her vil vi blive, thi dette er vort folks grænse! - Jeg siger alt dette i tillid til, at De mener det samme. For mig er dette syn baggrunden 
for den gerning, jeg har fảet lejlighed til at udøve i Sønderjylland - og bestemmende for mig i stort og småt i det politiske liv. Og netop med henvisning til vor historiske opgave siger jeg Dem nu en oprigtig tak for det henrundne år og onsker Dem alt godt $i$ det, der begynder $\mathrm{i}$ dag.

Deres hengivne

A. Torp. *

2. januar. $\mathrm{På}$ en rejse lærte jeg den tidligere tyske marinekaptajn Horst von Pflugh-Harttung - kendt som Karl Liebknecht's morder - at kende. Jeg har $\mathrm{i}$ et halvt år vedligeholdt forbindelsen med og fået ham interesseret i dansk-tyske grænsespørgsmål, hvilket jeg tillægger betydning, da han har forbindelse med de nuværende ledende politikere i Tyskland. Nu til nytår besvareda jeg et brev fra ham med bl. a. følgende: 'Allerede har De jo haft lejlighed til på en lykkelig måde at virke retningsgivende med hensyn til to for vore forhold vigtige tyske blade. Og det skulle meget glæde mig, om De ved hjælp af Deres udmærkede forbindelser $i$ Tyskland kunne få lejlighed til at virke videre $\mathrm{i}$ den retning, der så afgørende stemmer overens med hele Deres personlige indstilling over for det dansk-tyske forhold. Deres venner er det, som i dag har ledelsen i Berlin, meget ville være vundet, om disse personer fuldtud bibringes forståelse for, at den meste slesvig-holstenske grænsepolitik blot er smålig provinsialisme, der intet har med det tyske riges store interesser at gøre - disse interesser, som i Norden vil blive levende fremmet den dag, man giver til kende, at den afgørelse, som den tusindårige udvikling af forholdet mellem Tyskland og Danmark skabte i 1920, nu må stå ved magt. - Een gang må vi holde op med at stirre på dette græenseproblem og $i$ stedet finde hinanden til fremme af store fælles interesser. - Om dette skal lykkes beror jo så meget $\mathrm{p} \not ̊$, om de styrende påvirkes $\mathrm{i}$ den rigtige retning. At Deres forbliven i Danmark betyder et udmærket bidrag i den henseende, er jeg ikke i tvivl om c.

13. januar. Jeg besøgte $i$ går $H$. P. Hanssen, der var fuld af harme over, at en stor tysk gård ved Flensborg fjord (Rinkenæs) ikke var blevet købt, fordi Jordlovsudvalgets indstilling herom ikke var blevet godkendt af landbrugsministeriet, der fandt prisen 
for høj. H. P. Hanssen fremhævede, at når gården nu blev købt af Vogelgesang, ville den blive udstykket $i$ en halv snes tyske husmandsbrug ved dansk støtte $i$ henhold til loven. Med tiden ville der blive indrettet en tysk skole, ligeledes med dansk akonomisk støtte. Bortset fra den nationale svækkelse, hvad blev der så af de penge, landbrugsministeriet havde sparet ved ikke at købe. Tilfaldet er et bevis blandt mange andre på, at der ikke er tilstrækkelig oversigt over og samvirken mellem administrationens forskellige grene i vor grænsepolitik. Ellers ville man let se, at der intet var at spare ved ministeriets holdning og have købt gården. $I$ et radioforedrag havde $H$. P. Hanssen angrebet centraladministrationen og ganske særlig landbrugsministeriet. Departementschef Waage var blevet meget pinligt berørt deraf og givet udtryk derfor i et brev til H. P. Hanssen's svigersøn, amtmand Thomsen. Hanssen ville derfor gå op til Waage, når han kom til København, og fastholde sit standpunkt og forsøge at få ministeriet til at bære sig anderledes ad.

14. januar. Der holdtes for et par dage siden et møde i Højer for at søge Højer-banen bevaret. Til stede var medlemmer af kommunalbestyrelsen $i$ de interesserede sogne og byer - og borgmestrene Thomsen og Andersen (Højer) - begge tyske. Man enedes om at sende en deputation til København for at tale med det pågældende rigsdagsudvalg. Borgmester Thomsen fremhævede $\mathrm{da}$, at de danske repræsentanter skulle slå på den nationale betydning, banens opretholdelse har! Denne for en tysk borgmester overraskende holdning stod man også over for, når der var tale om at virke for bevarelsen af Tonder garnison - da fremhævede han samme synspunkt endog $i$ et byrådsmøde - på den mest selvfølgelige måde.

29. marts. Nazisternes overtagelse af magten har skabt megen uro om grænsen, og man må regne med den mulighed, at nogle af de ivrige nazistiske Sturmabteilungen syd for grænsen en skønne dag $i$ ungdommeligt overmod krænker grænsen og f. eks. marcherer ind $\mathrm{i}$ Tønder, hvor der $\mathrm{i}$ virkeligheden ikke findes nogen magt til at hindre dette eller til at jage dem ud. En sådan indmarch ville være en national blamage, og det ville være yderst uheldigt, især om ungdommen i Tønder, der ikke har kendt det tyske styre, således fik konstateret, at der også findes andre magt- 
faktorer end de danske. På alt dette henledte jeg opmærksomheden $i$ en samtale med en af de officerer, jeg under mine forhandlinger om Tønder garnison har lært at sætte megen pris pá, nemlig kaptajn C. Hedegaard i Kolding. Jeg udtalte da min tillid til, at der i hvert fald hurtigt kunne samles de nodvendige tropper for at jage et sådan korps ud af landet. Dette gentog og uddybede jeg senere $i$ et brev til kaptajnen, som kort tid efter igen besøgte mig bl. a. for at sige, at min tillid til, hvad der kunne gøres fra dansk side $i$ den navnte situation, ikke var berettiget. Om vinteren har vi næsten intet mandskab i garnisonerne, fordi der nu kun foregår rekrutuddannelse om sommeren, og det mandskab, der da er inde, er forst i stand til at præstere noget henimod november, når deres uddannelse er endt. Men da de ganske mangler øvelse, ville det være det rene slagteri at føre dem mod våbenøvet mandskab. Kaptajnen mente derfor, at der burde træffes særlige grænseforanstaltninger ved, at der i de sønderjyske garnisonsbyer indkaldtes f. eks. 500 af de hjemsendte såkaldte »a-1 soldater", som straks skulle gennemgå en befalingsmandsskole og iøvrigt holdes inde, så længe grænseuroen vedvarer. Med et sådant elitekorps ville man kunne skabe nogenlunde trygge forhold ved grænsen. Jeg gav min tilslutning til planen, som jo stemmer overens med regeringens standpunkt, at vi skal have et grænseværn til kamp mod "væbnede korps og organiserede bander", - som dr. Munch formulerer det. Jeg lovede at forelægge sagen for en af mine politiske forbindelser.

4. april. Om situationen har jeg skrevet folgende brev til professor Aage Friis:

sTak for Deres af 6 . f. m., som jeg modtog straks efter min hjemkomst fra København, hvor jeg havde lejlighed til at tale med Dem om situationen hernede, som De iøvrigt havde omtalt $\mathbf{i}$ Deres allerede afsendte brev til mig.

Siden har forholdene jo udviklet sig på en måde, hvis alvor ikke må undervurderes. Indførelsen af det nazistiske styre i Tyskland har blandt tyskere i Nordslesvig skabt en styrket tro på en grænseflytning mod nord - en tro, der rent psykologisk set kan være farlig. Forventningerne $i$ den retning er naturligvis blevet stærkt næret ved borgmester Sievers tale, som bl. a. giver mig anledning til denne henvendelse. Lige efter at talen var holdt, an- 


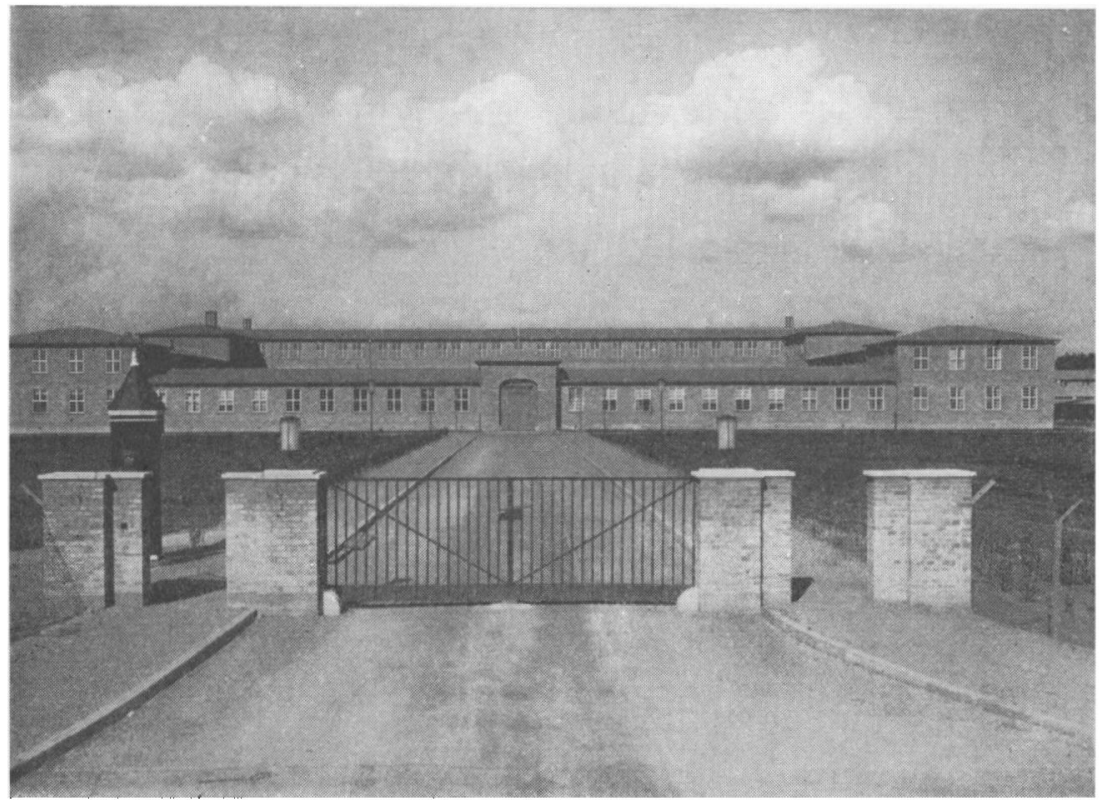

Tonder kaserne, fot. kort efter opforelsen. Allred Torp havde sammen med red. $F r$. Andresen en vesentlig andel $i$ den nye kasernes placering og opforelse.

modede $H$. von Pflugh-Hartung (Hotel »Phønix«), som De jo har lært at kende gennem II. P. IIanssen, mig om at meddele sig, hvorledes talen havde virket i befolkningen, og hvad jeg iøvrigt mente derom. Hvad jeg svarede i mit udførlige brev, kan De let tænke Dem - det behøver jeg slet ikke at komme nærmere ind på her. Som svar på min fremstilling modtog jeg omgående følgende:

Kobenhavn, den 29. 3. 1933.

\section{Lieber Herr Torp!}

Danke für Ihren Brief, mit dessen Gedanken ich vollkommen übereinstimme. Ich bin bereits an der Arbeit. Und möchte Ihnen deshalb einen vertraulichen Tip geben. Wäre es ev. möglich, dass man von offizielle Seite hier in dieser Sache aus dem bekannten Anlass eine mehr oder weniger offizielle Anfrage in der gleichen Richtung wie der Artikel in "Hejmdal " an die hiesige deutsche Stelle richtet? Dies braucht ja - am liebsten - nicht in die 
(Sffentlichkeit zu kommen. Vielleicht ein Gespräch unter 4 Augen?

Dies ist nur eine Anregung. die ich Ihnen geben möchte.

Mit herzlichem Gruss, in Eile

Ihr

Pflugh-Harttung. *

Jeg tror, man skal stille sig noget reserveret med hensyn til Pf.-H.'s indflydelse; den var i hvert fald sikkert større under den forrige regering, idet han stod mændene $i$ s Herrenklub * og dermed Schleicher nær. Af flere samtaler har jeg dog fảet det indtryk, at han har sin gang $i$ det tyske gesandtskab, og at han før regeringsskiftet var emne som tysk presseattaché. Jeg kan derfor ikke afvise en mulighed af, at han har grund til at vide noget om, hvorledes en henvendelse til det tyske gesandtskab vil blive modtaget, og jeg beder Dem derfor om at gøre dr. Munch opmærksom på brevet, som jeg sender til Dem og ikke direkte til ham, fordi jeg over for Dem kan bygge på Deres kendskab til afsenderen. Jeg må iøvrigt sige, at jeg ud fra mine muligheder for at bedømme situationen finder en henvendelse til det tyske gesandtskab påkrævet, men jeg håber rigtignok, at den har fundet sted straks efter, at dr. Sievers' tale var holdt. Men jeg føler mig ikke sikker derpå, fordi en să energisk optræden vel ikke stemmer med dansk fremgangsmåde over for Tyskland i lignende situationer. Jeg regner med tilbageholdenhed fra dansk side - en tilbageholdenhed, der vil være forståelig, men som de mest roligt tænkende mennesker her dog er tilbøjelige til at finde fejlagtig, fordi man mener, at en sådan holdning, der så dårligt stemmer med Tysklands agressive optræden over for udlandet - f. eks. Sverige - fra tysk side bliver taget som udtryk for svaghed, der blot vil give anledning til endnu mere tysk pågåenhed. En fast dansk tilbagevisning af Sievers' tale vil derimod formentlig medvirke til at skaffe os den nødvendige respekt hos tyskerne, hvis eventuelle ildesindede planer imod Danmark dog sikkert ikke opgives, fordi vi viser os ydmyge, når vi krænkes på en måde, som Tyskland aldrig selv ville finde sig $i$.

En anden ting, der optager sindene stærkt, er muligheden for en krænkelse af grænsen fra nazisternes side. Der er jo på gen- 
foreningsdagen planlagt en storstilet tysk demonstration syd fra imod grænsen, og der regnes med et masseopbud i det nærmeste grænseområde forbundet med en større flyvermanøvre ved Flensborg. Bølgerne vil da sikkert komme til at gå højt, og man kan vel ikke lukke øjnene for den mulighed, at et nazistisk korps $i$ ungdommeligt overmod går over grænsen og f.eks. marcherer ind $\mathbf{i}$ Tønder. En sådan begivenhed ville naturligvis være yderst uheldig; thi selv om vi snart kunne jage flokken ud igen, ville det dog være noget betænkeligt, om byens ungdom således fik demonstreret, at der også findes andre magtfaktorer end de danske. - Men kan vi tilstrækkeligt hurtigt jage urostifterne bort? Det har jeg hidtil ikke tvivlet om; thi i de mange forhandlinger angående Tønder garnison, jeg som byrådsmedlem i det sidste årstid har ført med hærledelsen, bl. a. general With, har jeg fået den oplysning, at der i den tidligere generalkommando i Viborg var udarbejdet planer til en hurtig sammentrækning af tropper $i$ Nordslesvig, hvis grænsen skulle blive overskredet. I et brev til en officer, hvis slægt hører hjemme i Vestslesvig, udtrykte jeg for nogen tid siden min tillid til denne ordnings effektivitet. Han skrev da omgående, at min tillid ikke var berettiget og bad mig nogen tid efter om en samtale. Han rejste her til byen under foregivende af at skulle tale med mig om byens kaserneforhold, men i virkeligheden kun for at sige mig, at under en situation som den tænkte var vor stilling yderst alvorlig. Vi ville aldeles ikke tilstrækkelig hurtigt kunne jage de fremmede bort, fordi vi normalt næsten aldrig har soldater i garnisonsbyerne, der kan tage kampen op mod et våbenøvet frivilligt korps. Som ordningen nu er, kan garnisonsbyerne hernede "tages på sengen" af en lille flok. Thi om vinteren foregår der ikke længere rekrutuddannelse, og da består garnisonens hele mandskab kun af ca. 50 garnisonstropper (arbejdssoldater), der blot kan forrette den nødvendige vagttjeneste. Da kan vi altså slet ikke yde nogen modstand på stedet. Og i sommerhalvåret er det ikke stort bedre, thi de rekrutter, vi har inde fra maj til november, kan først være blot til nogenlunde nytte mod slutningen af rekrutuddannelsen, og selv da vil deres værdi være tvivlsom, idet de da under en kamp vil være at sammenligne med skoledrenge, der umiddelbar efter deres udskrivning af skolen selv skulle overtage undervisningen. 
At føre dem ud til en regulær våbenkamp mod mænd, der har deltaget $i$ verdenskrigen, ville da betyde nedslagtning af disse unge, ganske uøvede soldater. Da Danmark imidlertid ikke kan foretage en regulær mobilisering i grænseområdet, bør vi i al stilhed indkalde 4 à 500 hjemsendte såkaldte a-1 soldater — altså dem, der er hjemsendt med det bedste vidnesbyrd både for miliIær dygtighed og god opførsel. Af dem skulle man danne et "sønderjysk krisevæern" eller lg. og straks gå i gang med at give dem den samme uddannelse som befalingsmandselever og så iøvrigt belıolde dem inde, indtil uroen drev over. Et sảdant korps af det hedste menneskemateriale under daglig fortsat ovelse ville kunne sikre grænsen mod krænkelse af de frivillige korps syd fra, som man må regne med. Udgifterne vil i virkeligheden ikke blive særlig stor, da man desværre mâ antage, at størstedelen af de påtrenkte indkaldte dog gâr arbejdslose og altså skal have understottelse, der kan spares under indkaldelsen.

Jeg bemærkede hertil, at hvis tanken skulle gennemføres, måtte det ske yderst stilfærdigt. Korpset burde intet navn have, og der skulle ikke afgives nogen officiel meddelelse om dets oprettelse. Man skylder jo - hvis finansudvalget i stilhed kunne enes om sagen - ikke nogen regnskab, og man kunne lade den stedlige befolkning leve $i$ den tro, at der blot var tale om en foranstaltning $i$ henhold til den nye garnisonsordning, som jo nu først skal føres ud i livet. Disse betragtninger var vedkommende helt enig med mig $i$, og efter at have overvejet sagen, refererer jeg den nu for Dem, idet jeg tilføjer, at det ikke skulle være regeringspartierne fremmed at gennemføre den foreslåede foranstaltning, hvis man mener, der er anledning dertil. Vort parti har altid sagt, at vi ikke skal føre krig, men kun være $i$ stand til at tage kampen op mod "væbnede korps og organiserede bander". Nu synes vi netop at stå over for disse »korps og bander *, og det er da berettiget at forvente, at regeringen virkelig viser, at den vil gøre det nødvendige for at kunne lose den militære opgave, som den har på sit program. Store dele af den sønderjyske, krigserfarne befolkning, der iøvrigt slet ikke tilhører regeringspartierne, deler regeringens syn på Danmarks indskrænkede militære evner, men de venter sikkert også til gengæld energiske foranstalt- 
ninger for at kunne løse den mulige grænsebevogtningsopgave, så man kan se, at der er alvor i regeringens militærpolitik.

Endelig vil jeg benytte lejligheden til over for Dem at omtale sindstilstandene i Nordslesvigs befolkning, efter at nazisterne har sejret. Det må da straks siges, at dette har givet tyskerne en så sikker tro på at komme tilbage til Tyskland, at den samtidig med at synes urimelig, dog kan være farlig nok bl. a., fordi den indgiver dem kraft til handling, der giver sig udslag i oprettelse af flere og flere tyske privatskoler og andre tyske foranstaltninger. Denne tro kan tænde nyt håb blandt de mange svage, der havde indrettet sig på en fremtid i Danmark for sig og deres efterkommere. $\mathrm{Nu}$ vækkes med fagre ord erindringen om den yode tyske lid «, og det går som en stille hvisken fra hus til hus i Tønders små sidegader, hvor de "alteingesessene småborgere har til huse: "Vi bliver tyske igen - vi kommer igen ind i det store folk med de rige muligheder ". Man oplever, at sådanne folk i fuld alvor siger til deres danske husfæller: $\gg \mathrm{Nu}$ bliver Tønder snart tysk, men så skal vi nok behandle jer godt, for danskerne har været gode mod os siden genforeningen ". - Eller man hører $i$ togene ældre besindige bønder tale om, hvor vidt "udløsningen " kommer straks, eller om der vil gå et par år endnu.

Det værste er, at alt dette har sin stille indflydelse i mange danske sind, der efterhånden vænner sig til den tanke, at grænsen ikke kan fastholdes. Man oplever, at folk derfor ikke vil købe ejendomme i grænseområdet, hvor en dansk bebyggelse netop er nødvendig, at et dansk amtsrådsmedlem fra den nordlige del af Tønder amt stiller sig imod vejanlæg i den sydlige del, "som tyskerne alligevel snart tager tilbage «. Det er naturligvis farligt, om en sådan sindsindstilling får lov til at brede sig; thi troen på, at grænsen ikke kan holde, kan let betyde tab af vilje og evne til virkelig at hævde den, når opgøret $i$ form af $f$. eks. en forventet ny afstemning skulle komme. Er grænsen først opgivet $i$ alles sind, er den halvvejs opgivet $i$ virkelighed.

Overfor dette må Danmark vise, at riget fastholder grænsen, og det kan bl. a. ske ved, at det sønderjyske jordlovsudvalg ikke af et småligt landbrugsministerium hindres $i$ den store opgave at købe jord og oprette nye hjem i grænseområdet. Hvis der foretages sådanne jordopkøb, vil befolkningen se, at Danmark frem- 
deles tror på grænsen, og vil da også selv fatte nyt mod til at bo og bygge $i$ landet. Endnu kan håbet og troen let fastholdes og genrejses, for man må naturligvis også regne med, at stormløbet fra syd kan virke som en indsprøjtning, der vækker den slumrende selvhævdelse, således som resultatet også blev af Vogelgesang-mødet $i$ sin tid. Dette erfarede jeg ved et stort idrætsstævne i Haderslev i søndags. Ved den festlige afslutning rejste en efter en af amtets unge bondesønner sig op og udtalte deres harme $i$ anledning af borgmester Sievers' tale. *Vi har længe talt om krise. Nu lader vi den tale fare og siger til tyskerne: Når I løber storm imod grænsen, så skal I få lov at løbe panden imod atter og atter. Det skal vi vise Jer; thi I skal vide, at det ja, vore fædre gav Danmark på afstemningsdagen, det står vi unge ved $i$ usvigelig troskab. " Dette var tonen, og sådanne ord har deres opbyggende værdi, men hvordan går det, når de unge kommer ud til en grå hverdag med små fremtidsmuligheder $i$ en tid, der er ond mod dem, der vil bygge hjem og være sig selv. Ja, da kan modløsheden komme, og da kan lokkende toner om Tyskland med de store muligheder, høje priser på bonden produkter o. s. v. øve virkning. Vi må derfor gøre noget netop for de unge ved, som direktør Hammerich foreslår, at give dem lettest mulig adgang til jord i grænselandet, hvis sikre garanti for en dansk fremtid de som bosiddende bønder da vil blive. Ved opkøb af jord vil man måske støde på vanskeligheder med hensyn til prisen, der ofte har været anset for at være for høj hernede. Mange køb er af den grund ikke blevet til noget, og i visse tilfælde har der vel ikke været stort at sige dertil, idet der naturligvis også skal tages økonomiske hensyn. Men der er desværre også sørgelige eksempler på, at man har opgivet jordkøb, der national-politisk set ville have været af den største værdi for os, og når sådanne køb ikke er blevet gennemfert, kan man som årsag bl. a. finde manglende planmæssighed og overblik i Danmarks genforeningspolitik. Så alvorlig, som situationen nu er, bør spørgsmålet om prisen på jord trænges $i$ anden række. Når talen er om at fastholde landsdelen - altså om en eksistenskamp - må vi have råd til at sælge den måske for dyrt erhvervede jord med tab, således at de unge, der skal dyrke den, kan sidde i den økonomiske tryghed, som ikke mindst i Danmarks egen interesse bør præge grænsebefolkningen. Jord- 
opkøb er et forsvarsmiddel, om hvis rentabilitet der ikke må tales for meget. Hvem venter udbytte af de store militærudgifter, som en krigerigsk hævdelse af landet vil medføre. Man er så indstillet på, at der hertil naturligvis må bruges millioner, der aldrig kommer igen. Hvordan kan man da stille sig så uforstående over den tanke at ofre nogle få hundredtusinde på jordop$k ø b$, der for Danmark dog vil betyde en sådan sikring af grænseområdet, som selv det størst mulige militærapparat ikke kunne yde. Hvorledes kan vi overhovedet betænke os på at tage landet i besiddelse og lade bondens børn rejse deres hjem på jorden for dermed at gennemføre og sikre den virkelige genforening. På baggrund af de mange forskærtsede muligheder i Sønderjyllands historie, må vi nu gribe beslutsomt til og løse denne opgave, hvis afgørende betydning alle er enige om.

Hvis vor grænse er ved at blive opgivet i visse svage danske sind, gælder det om, at vi ved vore handlinger med kraft tilkendegiver, at den skal fastholdes. Ved grænsedragningen blev der fra dansk side vist et sådant mådehold, at jeg synes, vi måtte miste vor selvagtelse, om vi da nu ikke også hævdede den med alle forsvarlige midler.

\author{
Med ærbødig hilsen \\ Deres hengivne \\ (sign.) A. Torp. *
}

\title{
MINDEORD
}

Lærer Alfred Torps sidste optegnelse er dateret den 4. april 1933. Den begivenhedsrige sommer har ikke levnet ham tid til at skrive dagbogsnotater, og derfor kan vi nu ikke læse hans egne referater af de vigtige forhandlinger og møder, han var med $i$ for at skabe et værn mod den frembrusende nazistiske bølge. Det var planen, at han med udgangen af 1933 skulle tage sin afsked som lærer for at overtage en vigtig post $i$ det nationale arbejde. Men da han den 3. december 1933 var på vej hjem fra en forhandling herom med H. P. Hanssen, blev han, formentlig henfaldet i dybe tanker, udsat for et automobilsammenstød $i$ det uoverskuelige og berygtede Raved-kryds, og han mistede livet herved. 
I Sprogforeningens Almanak hyldede vennen, amtslæge, dr. Lausten-Thomsen, hans minde i følgende ord:

» Kun få år fik han lov til at udføre sin gerning, men den blev så omfattende, at danske mennesker mindes ham med stor tak, sâ sorgen ved hans død blev ikke blot som ved en god dansk mands bortgang, den blev tillige sorg for gerning, der ikke blev udfort, men som vi med føje ventede på.

Torps minde vil blive bevaret i Sønderjylland. Vi synes, at vi så dårligt havde råd til at undvære hans kløgt, hans retsind, hans arbejdsevne, hans frisind, hans lyse og smukke personlighed *.

Og for Torps bäre blev ført bort fra T'ønder til fødebyen Nørre Sundby, holdt amtmand, lensgreve O. D. Schack en tale, der på smukkeste måde karakteriserer Torp som menneske og lærer, og som derfor ogsâ skal afslutte hans værdifulde optegnelser:

„På skoledirektionens vegne vil jeg mindes og takke den mand, der som dansk larer ved byens tyske skole ved elskværdighed og retsind vandt børnenes kærlighed og laerernes venskab.

Også på skolevæsenets område nåede hans interesse ud over den egne skolegård.

Interesseret som han var $i$ et sundt og moderne skolevæsen, har han of te fremsat sine meninger derom, både $\mathrm{i}$ fagpressen og på lærermøder. Ved siden af at være saglig var hans opfattelse altid velbegrundet, og hans navn havde derfor en god klang i den danske skoleverden.

Dette er kun en del og næppe den storste af det, vi mistede ved lærer Torps uventede bortgang. Byrådet vil savne et dygtigt medlem, der havde en fremragende andel $i$ de for Tønder så vigtige indlemmelses- og kasernespørgsmål, og byen har mistet en nidkær talsmand, når det gjaldt om at føre kommunens anliggender frem i hovedstaden.

Men det, som navnlig, og fra så godt som alle sider, fremhæves om den afdøde, det er hans indstilling overfor grænselandet og de opgaver, han der havde foresat sig, ja, tildels allerede havde løst. Han gik til arbejdet, besjælet af en ren idealisme, men tog fat på del på den sagligste måde. Han kendte Slesvigs historie bedre end de allerfleste og navnlig havde han, da han i 1920 øjnede sin opgave hernede, studeret tiden mellem krigene $50 \mathrm{og} 64$ som et vigtigt grundlag for en ny og rigtigere opfattelse. 


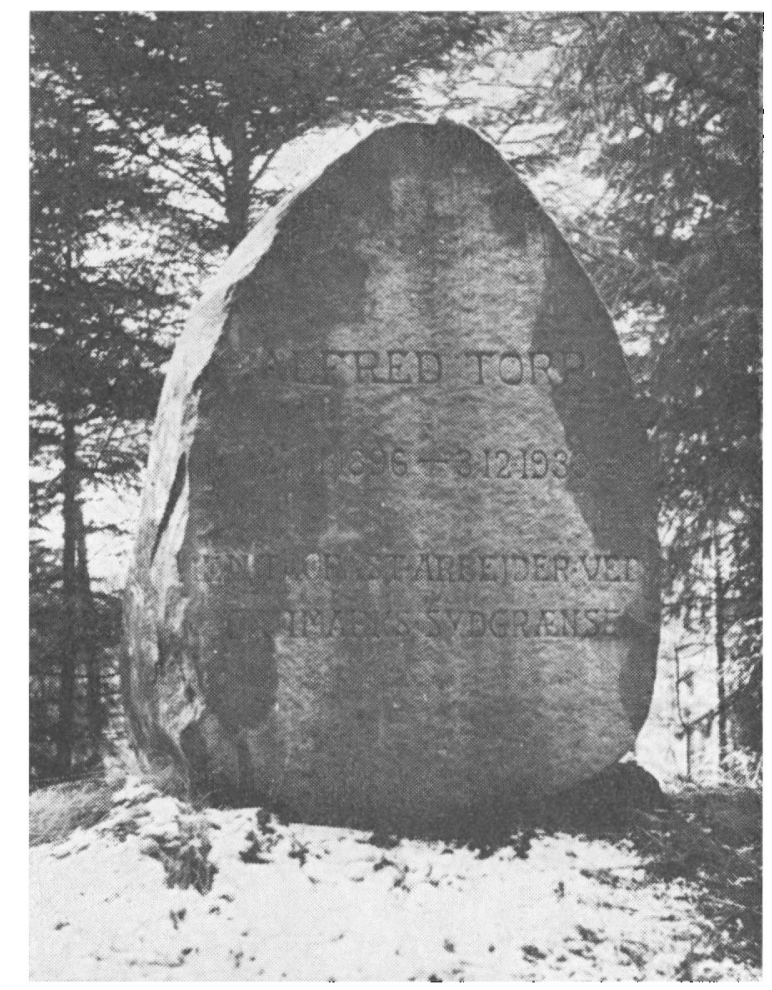

Mindesten for Alfred Torp $i$ Hojbjerg plantage. På stenen lases: „En trofast arbejder ved Danmarks sydgranse“.

Fot. A. Gabs, 1965.

Med åbent sind og redelig vilje til at opfatte forholdene, som de var, og ikke som han ønskede dem, studerede han nationalitetsbrydningerne her $\mathrm{i}$ landsdelen, syd for grænsen og ikke mindst på rejser $i$ andre lande med lignende forhold. Han var derved allerede nu bleven en autoritet pâ mindretalsspørgsmålenes område, der mere og mere blev opsøgt af de ofte betydelige repræsentanter fra andre mindretal og andre folk, der ville studere spørgsmálet her, og hans opfattelse og beretninger havde vægt på grund af deres saglighed, grundighed og det sunde omdømme, der prægede dem.

Men denne dygtighed var det ikke alene, der gjorde ham egnet til at bo $i$ en grænseby som Tonder. IIer, hvor kærligheden til land eller nationalitet er tilstede, enten den giver sig synlige ud- 
slag eller virker som en stille, men stærk understrøm, ville han ikke have kunnet gro, derson det ikke havde været hans varme fadrelandssind, der havde drevet ham til at blive sit land en hjælper og vejleder pâ en jordbund, hvor gode hensigter ikke er nok, men et nøje kendskab til forholdene må vejlede den gode vilje.

Derfor kunne han også forstå den tilsvarende nationalitetsfølelse hos den anden side, og han havde lov til at regne med, at hans ønske om at løfte forholdet mellem danske og tyske op i det højere plan, hvor stærkt og godt fra begge sider kan modes, også ville agtes eller deles af hans tyske medborgere.

Han var rigt udrustet som fá til at betyde noget godt her $i$ grænsebyen. Det venlige, rolige og gode, der lå $\mathrm{i}$ hans sind, har måske få haft bedre adgang til at blive fortrolig med, end hans tyske skolebørn, og den gråd og sorg, hans død har forvoldt dem, er sikkert så dybtfølt som hos nogen voksen.

De, der fik lov til at følge hans gerning hernede, måtle beundre hans tanke og dømmeevne, der var som en klar flamme og var parret med en ganske upersonlig given sig hen til sagen, der lå ham på hjerte. Vi, der således kom i nærmere berøring med ham, kunne ikke andet end blive hans venner og følge hans stræben med stedse voksende forhåbninger.

Ja, det, der syntes at særpræge ham mest, ung som han så ud, og med noget næsten barnlig-renligt over sig, var, at han tiltrods for sin mandige og målbevidste gerning og det meget, han allerede havde udrettet, havde det tilfælles med børnene, han underviste, at han havde fremtiden for sig. Der var få, måske ingen, af hvem man her ventede sig mere - og nu står vi ved hans kiste med savn og bristede forhåbninger.

Derfor tegner vi billedet af hans evner og stræben så rent og skønt, vi formår, for at ungdommen $i$ grænselandet kan være et skønt forbillede rigere.

Men han er nu der, hvor grænsens sang ikke når hen og hvor alt det, der her fyldte og optog ham, svinder bort som skygger. Ville han se tilbage på det, han forlod, så var måske af alt, børnenes tårer det minde, han helst ville tage med sig på det langsomme tog ud af byen, hvis gode danske borger han var.

Så siger vi da farvel, og tag så vor, tag det Sønderjyllands tak, som du tjente så godt, med på vejen. * 